\title{
Pathogenic Genome Signatures That Damage Motor Neurons in Amyotrophic Lateral Sclerosis
}

\author{
Ali Yousefian-Jazi ${ }^{1}$, YunHee Seol ${ }^{1}$, Jieun Kim ${ }^{1}$, Hannah L. Ryu ${ }^{2}$, Junghee Lee ${ }^{2,3, *}$ \\ and Hoon Ryu 1,2,*D \\ 1 Center for Neuroscience, Brain Science Institute, Korea Institute of Science and Technology, \\ Seoul 02792, Korea; yousefian@kist.re.kr (A.Y.-J.); yseol@kist.re.kr (Y.S.); jieunkim@kist.re.kr (J.K.) \\ 2 Department of Neurology, Boston University Alzheimer's Disease Center, Boston University School of \\ Medicine, Boston, MA 02118, USA; hr1@wellesley.edu \\ 3 VA Boston Healthcare System, Boston, MA 02130, USA \\ * Correspondence: junghee@bu.edu (J.L.); hoonryu@kist.re.kr (H.R.)
}

Received: 3 November 2020; Accepted: 9 December 2020; Published: 15 December 2020

\begin{abstract}
Amyotrophic lateral sclerosis (ALS) is the most frequent motor neuron disease and a neurodegenerative disorder, affecting the upper and/or lower motor neurons. Notably, it invariably leads to death within a few years of onset. Although most ALS cases are sporadic, familial amyotrophic lateral sclerosis (fALS) forms $10 \%$ of the cases. In 1993, the first causative gene (SOD1) of fALS was identified. With rapid advances in genetics, over fifty potentially causative or disease-modifying genes have been found in ALS so far. Accordingly, routine diagnostic tests should encompass the oldest and most frequently mutated ALS genes as well as several new important genetic variants in ALS. Herein, we discuss current literatures on the four newly identified ALS-associated genes (CYLD, S1R, GLT8D1, and KIF5A) and the previously well-known ALS genes including SOD1, TARDBP, FUS, and C9orf72. Moreover, we review the pathogenic implications and disease mechanisms of these genes. Elucidation of the cellular and molecular functions of the mutated genes will bring substantial insights for the development of therapeutic approaches to treat ALS.
\end{abstract}

Keywords: amyotrophic lateral sclerosis; motor neuron; genome signature; cell damage; neurodegeneration

\section{Introduction}

Amyotrophic lateral sclerosis (ALS) is a progressive neurodegenerative disease characterized by both upper and lower motor neuron degeneration, paralysis, and ultimately limiting survival from two to five years after onset [1]. Disease onset typically occurs in late middle-life with the mean age being 65 years. It results in relentless progressive muscle atrophy and weakness, ending with respiratory failure [2,3]. In addition, this neurodegenerative disorder has an estimated worldwide mortality rate of 30,000 patients per year [4]. ALS cases are estimated to occur in 2-3 per 100,000 individuals in Europe, and less than one in Asia [5], thus categorizing it as a rare disease. Furthermore, up to $10 \%$ of ALS-affected individuals have an affected family member or members with familial ALS (fALS), in which most have inherited the disease in an autosomal dominant manner [6]. The remaining ALS patients, with no clear genetic linkage, are called sporadic ALS (sALS) [7]. At present, mutations in over 50 genes have been shown to contribute to the ALS pathogenesis [8,9]. Some of them such as SOD1, C9orf72, FUS, and TARDBP were shown to present deleterious mutations, while other variants mostly found by association studies rarely occur in the less frequent genes [8-10]. Several studies have identified oxidative stress, glutamate excitotoxicity, apoptosis, neurofilament dysfunction, protein misfolding and aggregation, impairment of RNA processing, disrupted axonal transport, endosomal trafficking 
dysfunction, inflammation, and mitochondrial impairment as the molecular pathways which lead to the disease and indicate ALS pathogenesis. RNA metabolism and protein metabolism have been indicated as commonly proposed ALS pathogenic mechanisms [11].

Since the end of the 19th century, there have been many studies on ALS, but its pathogenesis is still unclear [4]. Many genetic variants that contribute to the missing heritability of ALS are yet to be discovered. Nowadays, the number of studies on finding novel ALS genes and their functions on disease pathogenesis is growing quickly [12-20]. This review discusses the current genetic understanding and landscape of ALS and summarizes its disease mechanisms. Here, we specifically review the genes involved in ALS in three categories, the most prevalent, the less frequent $(\leq 1 \%)$, and the most recent ALS genes, and depict how genomic signatures turn into pathogenic molecules in ALS.

\section{Genetics of ALS}

To date, $5-10 \%$ of all ALS cases suffer the known mutant genes [21,22]. SOD1 is the most frequently mutant gene with $20 \%$ prevalence; mutant TARDBP and FUS in $5 \%$ and $4 \%$ of fALS cases, respectively, have been identified as well. In the United States and Europe, $40 \%$ of fALS cases suffer C9orf 72 variants, and the rest are caused by variants in other known or unknown genes (Figure 1) [23]. Simultaneously, variants in C9orf72 and SOD1 genes, which occur most frequently, constitute $7 \%$ and $1 \%$ of sALS cases, respectively [24]. To provide historical context, we illustrate the yearly number of publications from PubMed that include the terms "ALS" and "the gene name" in the title and abstract (Figure 1C). According to the timeline of gene discoveries, SOD1, TARDBP, FUS, and C9orf72 are the first to fourth genes found with more than $1 \%$ occurrences in the patients in the years 1993, 2006, 2009, and 2011, respectively. Furthermore, there are some genes involved in ALS with less frequent variants $(\leq 1 \%)$ (Table 1) and several recent genes over the past two years with relatively rare variants such as CYLD, S1R, GLT8D1, and KIF5A, which are precisely discussed in this review.

A

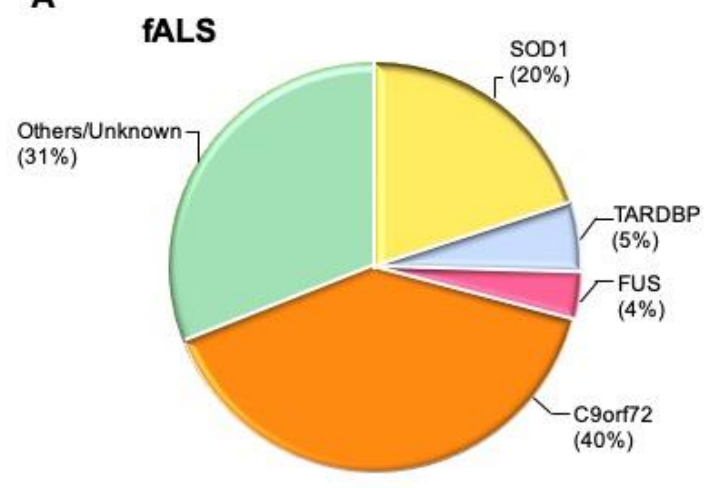

SOD1 1 TARDBP $₫$ FUS $=$ C9orf72 $\approx$ Others/Unknown

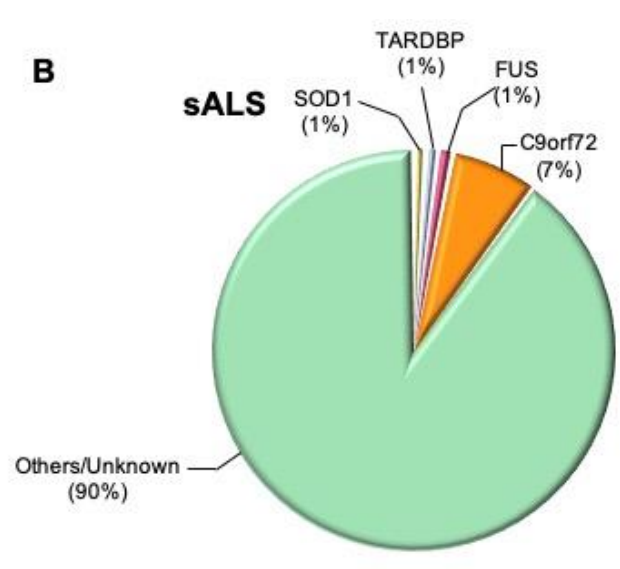

SOD1 1 TARDBP $=$ FUS $=$ C9orf72 $\|$ Others/Unknown

Figure 1. Cont. 

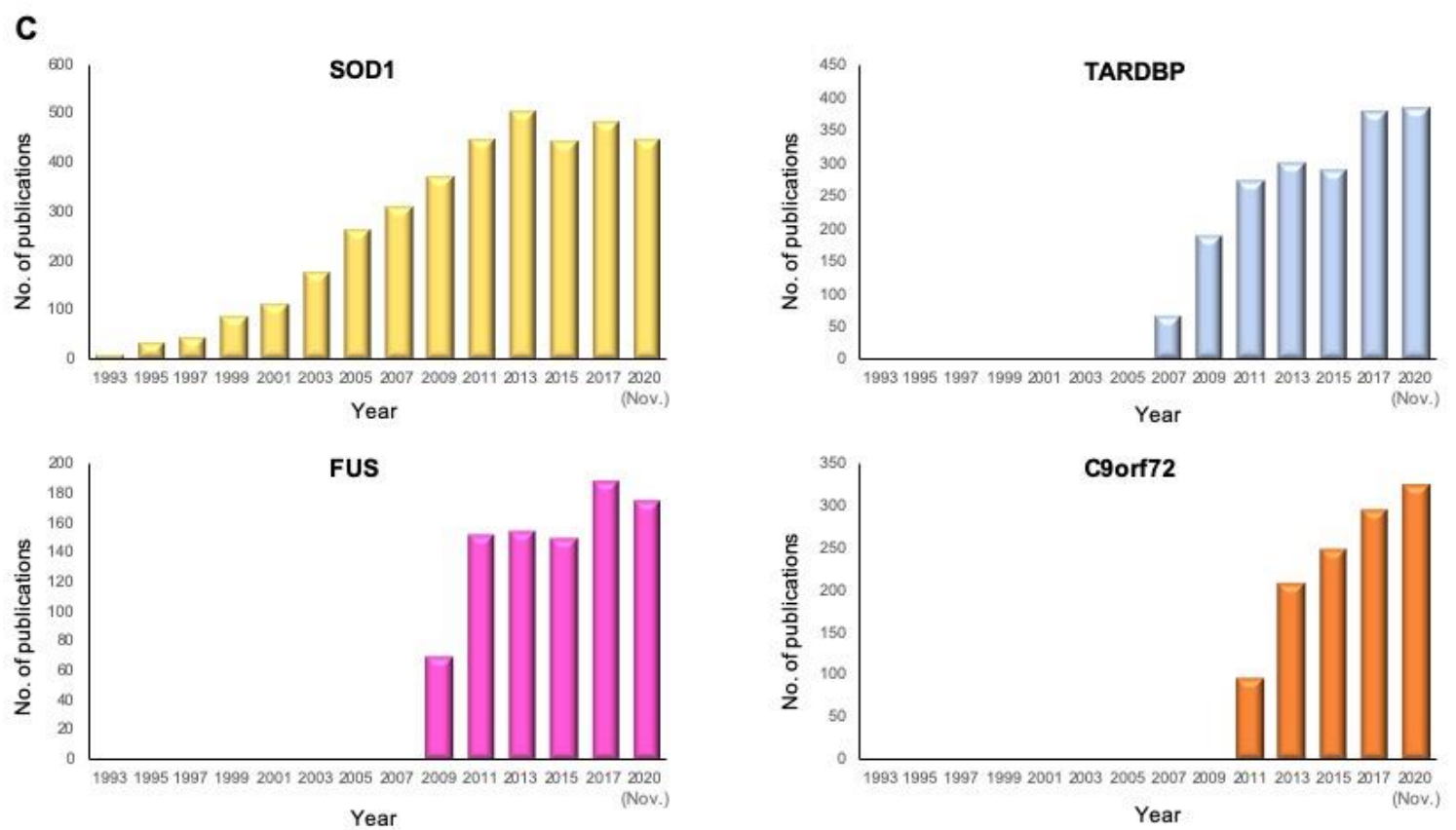

Figure 1. Proportional contribution of mutated genes in ALS and timeline of ALS gene study. (A) The proportion of mutant genes in fALS cases. (B) The proportion of mutant genes in sALS cases. (C) Timeline of ALS gene discoveries and researches for SOD1, TARDBP, FUS, and C9orf72. The Y-axis shows the number of publications in PubMed that include the terms "ALS" and "the gene name" by year until November 2020.

Table 1. Genes known to carry ALS-causing mutations.

\begin{tabular}{ccccc}
\hline Gene & Cases/Control & Frequency (Familial) & Frequency (Sporadic) & Reference (s) \\
\hline SOD1 & $2874 / 6405$ & $20 \%$ & $1 \%$ & {$[25]$} \\
TARDBP & $526 / 1262$ & $4 \%$ & $1 \%$ & {$[26]$} \\
OPTN & $673 / 781$ & $<1 \%$ & $<1 \%$ & {$[21]$} \\
SPG11 & $3056 / 900$ & $<1 \%$ & $<1 \%$ & {$[27]$} \\
VCP & $288 / 1569$ & $1 \%$ & $1 \%$ & {$[28]$} \\
hnRNPA1 & $517 / 625$ & $<1 \%$ & $<1 \%$ & {$[29]$} \\
ATXN2 & $915 / 980$ & $<1 \%$ & $<1 \%$ & {$[30]$} \\
ANG & $1629 / 1264$ & $<1 \%$ & $<1 \%$ & {$[31]$} \\
CHCHD10 & $4853 / 1991$ & $<1 \%$ & $<1 \%$ & {$[32]$} \\
SIGMAR1 & $158 / 1100$ & $<1 \%$ & $<1 \%$ & {$[33,34]$} \\
FIG4 & $473 / 558$ & $<1 \%$ & $<1 \%$ & {$[35]$} \\
SETX & $49 / 100$ & $<1 \%$ & $<1 \%$ & {$[36]$} \\
SQSTM1 & $546 / 738$ & $1 \%$ & $<1 \%$ & {$[38]$} \\
TBK1 & $252 / 827$ & $1 \%$ & $1 \%$ & {$[39]$} \\
NEK1 & $1022 / 7315$ & $1 \%$ & $<1 \%$ & {$[40]$} \\
TAF15 & $357 / 1100$ & $<1 \%$ & $1 \%$ & {$[41]$} \\
FUS & $583 / 1446$ & $4 \%$ & $<1 \%$ & {$[42]$} \\
ALS2 & $42 / 533$ & $<1 \%$ & $<1 \%$ & {$[43]$} \\
VAPB & $24 / 400$ & $<1 \%$ & $<1 \%$ & {$[44]$} \\
NEFH & $530 / 447$ & $<1 \%$ & $7 \%$ & {$[45]$} \\
C9orf72 & $696 / 909$ & $40 \%$ & $<1 \%$ & {$[46]$} \\
CHMP2B & $400 / 640$ & $<1 \%$ & $<1 \%$ & {$[47]$} \\
MATR3 & $108 / 1051$ & $<1 \%$ & $<1 \%$ & {$[48]$} \\
PFN1 & $274 / 1089$ & $<1 \%$ & & \\
\hline & & & $\%$ & \\
& & $\%$ & $\%$ & $\%$ \\
\end{tabular}


Table 1. Cont.

\begin{tabular}{ccccc}
\hline Gene & Cases/Control & Frequency (Familial) & Frequency (Sporadic) & Reference (s) \\
\hline PRPH & $189 / 380$ & $<1 \%$ & $<1 \%$ & {$[49]$} \\
TUBA4A & $363 / 5510$ & $1 \%$ & $<1 \%$ & {$[50]$} \\
ELP3 & $781 / 702$ & $<1 \%$ & $<1 \%$ & {$[51]$} \\
DCTN1 & $333 / 200$ & $<1 \%$ & $<1 \%$ & {$[52]$} \\
EWSR1 & $817 / 1082$ & $<1 \%$ & $<1 \%$ & {$[53]$} \\
GLE1 & $933 / 190$ & $<1 \%$ & $<1 \%$ & {$[54]$} \\
UBLLN2 & $200 / 928$ & $<1 \%$ & $<1 \%$ & {$[55]$} \\
\hline
\end{tabular}

\subsection{The Newly Identified ALS-Associated Genes (2018-2020)}

Several novel ALS-associated genes have been proposed by the researchers over the past two years. Farhan et al. identified DNAJC7 as a novel gene for ALS that encodes a member of the heat-shock protein family, HSP70, and has a key role in protein function such as protein folding and stabilization. Alteration of $H S P 70$ and DNAJC7 gene expressions causes protein aggregation in ALS model [17]. Another gene, WDR7, was proposed by Course et al., in which the human-specific $69 \mathrm{bp}$ variable number tandem repeat in the last intron of this gene may be associated with ALS. WDR7 repeat expansions may act similar to the specific range of CAG repeat expansion numbers at ATXN2, which are enriched in ALS cases. It was shown that WDR7 repeat expansion could form microRNAs, RNA aggregates, and lead to RNA editing [18]. Further study has shown that ATXN1 overexpression disturbs TDP-43 nucleocytoplasmic transport, which leads to a decrease in the nucleocytoplasmic ratio of TDP-43. Hence, mislocalization and aggregation of TDP-43 can be considered the hallmark of ALS [19]. Finally, ACSL5, a neurotoxic A1 astrocyte-related gene, is upregulated in ALS cases. ACSL 5 can induce A1 astrocytes, leading to motor neuron death and ALS progression. Overexpression of ACSL5, similar to the previously discovered gene GPX3, is associated with rapid weight loss in humans $[8,20]$. Although the mentioned genes above have been identified as ALS associated genes, the study on their contribution to ALS pathogenesis is still limited.

Dobson-Stone et al. identified a novel missense variant in CYLD gene as the genetic cause of ALS in a large European Australian family [16]. Previously, they found a disease locus on chromosome 16 by genome-wide linkage analysis [56]. The missense variant in CYLD leads to alteration of CYLD immunoreactivity in the brain tissue [16], and shows two ALS-associated pathological phenotypes: an elevation of cytoplasmic TDP-43 level [57] and an impairment of autophagy function [58]. Overexpression of CYLD inhibited transport of TDP-43 into the nucleus from the cytoplasm. In the nucleus, TDP- 43 controls the expression of ATG7, which mediates the fusion of lysosomes with autophagosomes. Decreased expression of ATG7 resulted in a loss of autolysosome formation [57-59]. Notably, overexpression of $C Y L D$ leads to the failure of autophagosome-lysosome fusion, causing the malfunction of autophagy $[16,60]$ (Figure 2A). 


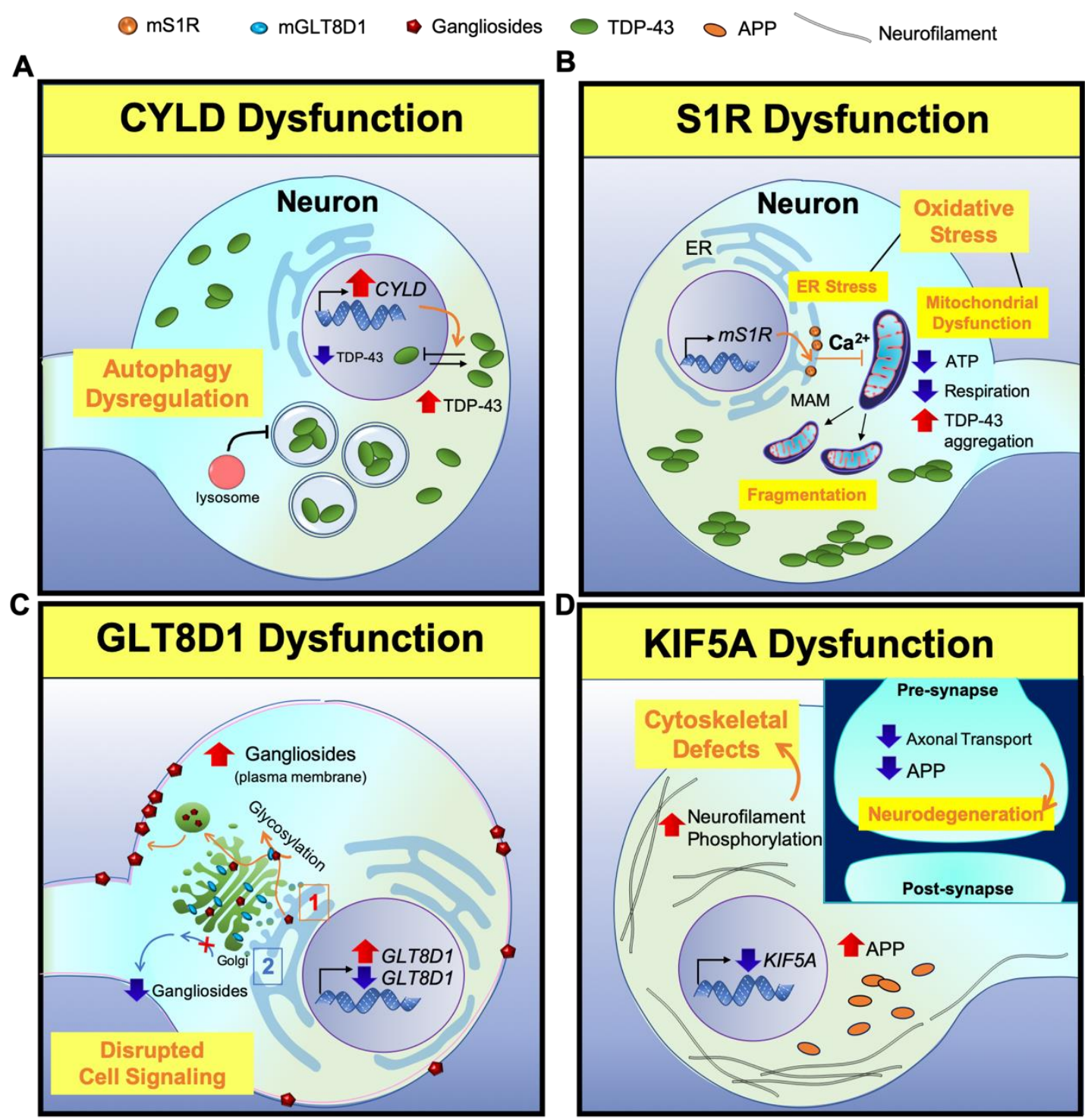

Figure 2. A scheme for illustrating neuropathogenesis of $C Y L D, S 1 R, G L T 8 D 1$, and KIF5A genes in ALS. (A) CYLD: Overexpression of CYLD inhibits the nuclear transport of TDP-43 from the cytoplasm, leading to the mislocalization of TDP-43. Lower TDP-43 level in the nucleus decreases the expression of ATG7, which is responsible for the fusion of lysosomes with autophagosomes. This results in a loss of autolysosome formation, causing a loss of autophagy function. (B) S1R: Mutant S1R leads to ER calcium and ATP depletion and perturbs mitochondrial dynamics and respiration. Subsequently, depletion of ATP leads to TDP-43-induced toxicity. (C) GLT8D1: (1) Mutant GLT8D1 increases the ganglioside signaling, leading to the transit of mature gangliosides to the cell membrane where they disrupt cell signaling. (2) On the other hand, knock down of GLT8D1 impairs its glycosyltransferase activity from the Golgi and diminishes ganglioside signaling. (D) KIF5A: Lack of KIF5A expression disrupts axonal transport, accumulates phosphorylated neurofilaments and APP, and causes cytoskeletal defects in neurons. (Inlet) In contrast, the disruption of axonal transport reduces APP level in the synapse and triggers neurodegeneration.

Sigma-1 receptor $(S 1 R)$, another potential therapeutic target gene in ALS discovered by Couly et al., regulates mitochondrial respiration and controls cellular defense against endoplasmic reticulum and oxidative stress [15]. S1R is mainly located in a special compartment of the Endoplasmic reticulum (ER) called the mitochondria-associated membrane (MAM) and has a role in ATP production [61]. S1R also protects TDP-43-induced toxicity by rescuing ATP production. ATP binds to the N-terminal 
domain of TDP-43 to enhance its oligomerization, and prevents the aggregation of TDP-43 into its toxic form [62]. Mutant S1R (mS1R) leads to ATP depletion and perturbs mitochondrial dynamics and respiration [15]. Therefore, it is demonstrated that an overexpression of $\mathrm{mS1R}$ is neurotoxic, leading to mitochondrial dysfunction, thus highlighting the role of S1R in ALS therapy [15] (Figure 2B). A recent study demonstrated that $\mathrm{mS1R}$ leads to Drosophila photoreceptor organization alteration and spontaneous walking behavior [15]. Moreover, the motor performance in S1R knockout mice diminished including muscle weakness, axonal degeneration, and loss of motor neuron [63]. Finally, the protective role of S1R has been dementated in the ALS mice (G93A) model with S1R knockout by behavioral and longevity experiments [64].

Cooper-Knock et al. proposed variants in the GLT8D1 gene which are recognized to be causal in ALS $[14,65]$. GLT8D1, expressed within the Golgi, is a member of the glycosyltransferase family 8 involved in catalyzing the transfer of glycosyl groups. In addition, gangliosides are synthesized in the ER, which are remodeled to maturation from the cis-Golgi to the trans-Golgi network via glycosylation by GLT8D1 [66]. The mature gangliosides, which are moved to the cell membrane, are involved in cell signaling [67] and produce neuroinflammation in motor neurons. ALS-associated mutations in GLT8D1 prevent the normal activity of glycosyltransferase enzyme and negatively impacts ganglioside signaling. The overexpression of mutant GLT8D1 increases ganglioside signaling, which leads to the transit of mature gangliosides to the cell membrane where they disrupt cell signaling. In contrast, the knock down of GLT8D1 impairs its glycosyltransferase activity from the Golgi and diminishes ganglioside signaling. The previous study demonstrated that both knock down and overexpression of mutant GLT8D1 induce motor neuron dysfunction and produce cytotoxicity in zebrafish consistent with ALS. In the previous studies, genetic variants in this gene showed a significant increase in disease severity and cytotoxicity in ALS patients [14,68] (Figure 2C).

Thus far, several studies have described the clinical evolution and the genetic findings of the KIF5A gene in sALS and fALS $[12,13,69,70]$. The genome-wide association study comparing 20,806 ALS cases and 59,804 controls discovered KIF5A as a novel gene associated with ALS [13]. Independently, rare variant analysis was conducted on 426 patients with fALS and 6137 control subjects, which identified enriched KIF5A splice-site variants in the cases. The genetic variants associated with ALS are located at the C-terminal cargo-binding tail domain of the KIF5A gene, which is also expressed in neurons. Considering the contribution of axonal transport deficits in the pathogenesis of motor neuron degeneration [71-73], variants in KIF5A disrupt axonal transport and amyloid precursor protein (APP) depletion in the synapse, which causes neurodegeneration. Therefore, a lack of KIF5A expression, which transports cargo by binding to distinct adaptor proteins, has been associated with the accumulation of phosphorylated neurofilaments and APP in the neuronal cell, which leads to cytoskeletal defects [13,74]. Moreover, previous studies confirmed the involvement of intracellular transport processes and strengthened the role of cytoskeletal defects of mutated KIF5A in ALS pathogenesis (Figure 2D). The first genotype-phenotype relationship showed that ALS patients with KIF5A loss-of-function mutations correlated with disease onset at an earlier age and longer survival [13]. The second was proposed by Brenner et al., in which adult onset, rapid progression, and early death were shown in the patients with KIF5A splice-site mutations [12].

\subsection{The Old Genes with Important Contribution to ALS}

SOD1, TARDBP, FUS, and C9orf72, as the oldest and most frequently mutant ALS genes, are described and their function in ALS pathogenesis are illustrated (Figure 3). 
A

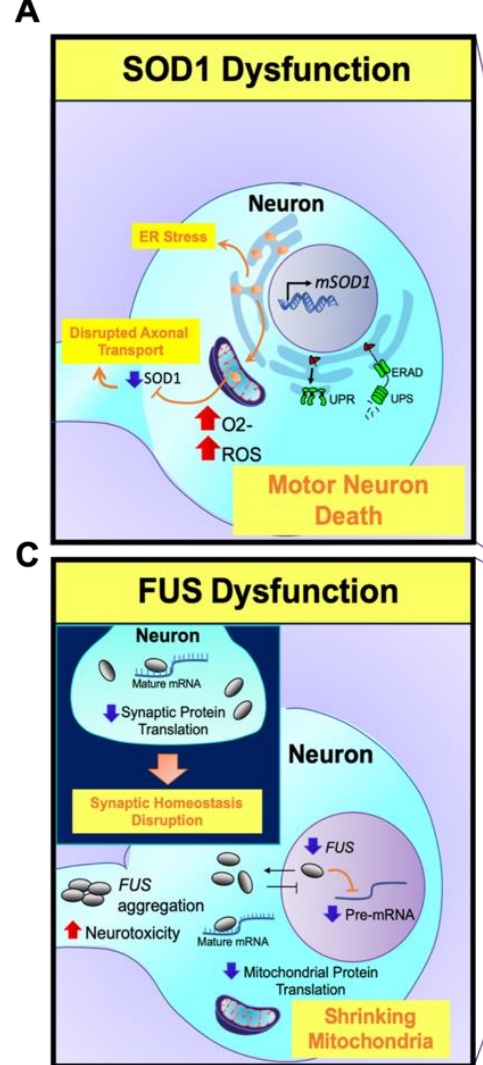

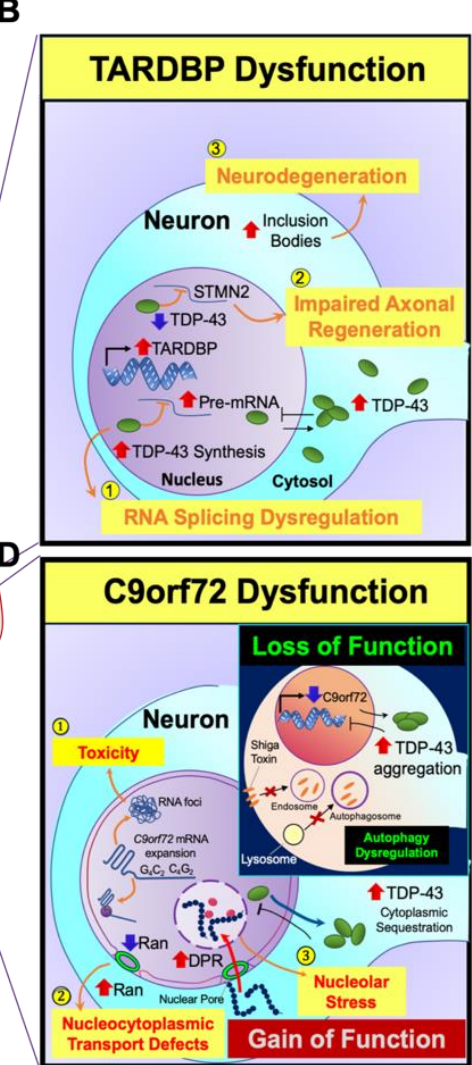

Figure 3. A scheme for illustrating neuropathogenesis of mutant genes (SOD1, TARDBP, FUS, and C9orf72) with major contribution to ALS. (A) SOD1: Mutant SOD1 (mSOD1) leads to oxidative stress by elevating free radicals that damage protein folding and impair axonal transport in motor neurons. Additionally, misfolded mSOD1 protein is not able to transport across mitochondrial membranes and accumulates onto the outer mitochondrial membrane, triggering motor neuronal death. On the other hand, mSOD1-induced ER stress results in the activation of UPR and ERAD, causing motor neuronal damage. (B) TARDBP: (1) Mutant TDP-43 (mTDP-43) is aggregated in the cytosol and TDP-43 dysfunction abnormally accumulates mRNA in the nucleus. (2) The loss of nuclear TDP-43 function leads to inhibition of TDP-43 binding to STMN2 RNA and mis-splicing of STMN2 RNA, which subsequently inhibits axonal regeneration of motor neurons. (3) On the other hand, upregulation of cytoplasmic TDP-43 forms inclusion bodies and it further propagates to neighbor cells, causing motor neuronal degeneration. (C) FUS: Mutant FUS (mFUS) disrupts nucleocytoplasmic transport and leads to its depletion from the nucleus. Then, mFUS aggregates in the cytoplasm and induces neurotoxicity. mFUS may also disrupt translation of transcripts associated with mitochondrial function, which leads to mitochondrial shrinkage. (Inlet) Moreover, mFUS binds to mature mRNAs in the cytoplasm and affects mRNA translation. Suppressed protein translation impairs the dendrites and axon terminals. Inhibition of local intra-axonal protein translation, that are required for synaptic maintenance and function, causes synaptic defects and dysfunctions. (D) C9orf72: (1) The nuclear RNA foci are generated by the aggregation of repeat-containing C9orf72 RNAs in the nucleus and cause neurotoxicity. (2) Sequestration of RanGAP by G4C2 RNA disrupts the nucleocytoplasmic transport function. The loss of nuclear Ran depletes nuclear TDP-43 levels and elevates cytoplasmic TDP-43 levels. (3) Furthermore, the imported dipeptide repeats (DPRs) into the nucleus are associated with nucleolar proteins and cause nucleolar stress. (Inlet) The loss of C9orf72 function in endosomal trafficking regulation by interactions with nuclear pore complex proteins eventually increases cytoplasmic TDP-43 inclusions. Furthermore, reduction of C9orf72 expression inhibits Shiga toxin transportation from the plasma membrane to the Golgi apparatus, and alters the ratio of LC3, an autophagosome marker, leading to autophagy dysregulation. 


\subsubsection{SOD1}

The SOD1 gene (encoding superoxide dismutase $1(\mathrm{Cu} / \mathrm{Zn})$ ), which maps to chromosome 21q22.1, was the first gene identified in fALS [75]. According to a recent genome-wide meta-analysis, approximately $15-30 \%$ of fALS and less than $2 \%$ of sALS cases have been identified to have the pathogenic variants of SOD1 [24]. Currently, 180 genetic variants have been discovered to affect the functional domains of the SOD1 gene including D90A, which is identified as the most frequent missense variant (Figure 4). Recently, the SOD1 homozygous truncating variant, c.335dupG, with total absence of SOD1 activity was identified in ALS affected patients [76]. Depending on the genetic variant, different molecular morphological changes can result, and patients with SOD1-related ALS who harbor particular variants have distinct clinical features $[10,77]$. For example, patients with the A4V, H43R, L84V, G85R, N86S, and G93A variants show rapid disease progression and shorter survival times, while patients carrying the G93C, D90A, or H46R variants show a longer life expectancy [78].

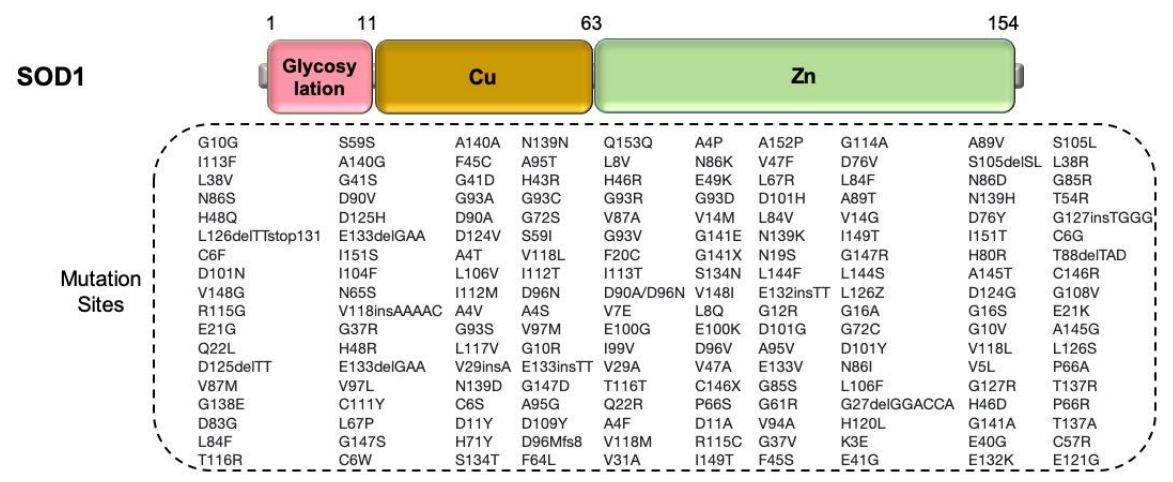

Figure 4. A scheme for exhibiting variant sites in SOD1 protein. (Top) the SOD1 protein structure; (Bottom) 180 SOD1 variants shown in ALS cases. Data were taken from the ALS online database (ALSoD) [79]. The variations are only identified on the amino acid sequence of the protein, and not all are proven to be pathogenic for ALS.

SOD1 is an antioxidant homodimeric protein of 153 amino acids, containing one copper and one zinc atom $[22,80]$. It can be localized from nucleus to cytosol or mitochondrial intermembrane space. The function of SOD1 is to protect cells from reactive oxygen species toxicity. Both copper and zinc play specific roles in SOD1 activity and structural stability, respectively, and are directly involved in the deactivation of toxic superoxide radicals $[22,81,82]$. Previous studies have supported that SOD1-ALS is caused by a gain of function, increasing the function of producing free radicals [83]. Mutant SOD1 modifies the oxidative activity, which causes accumulation of toxic hydroxyl radicals $[77,84]$. Accumulation of free radicals in the intermembrane space of the mitochondria leads to mitochondrial damage and disrupted protein folding, significantly affecting distal axons of motor neurons $[82,85,86]$. ER is a cellular compartment including chaperone-assisted proteins to help fold proteins. Mutant SOD1 activates ER stress which leads to activation of the unfolded protein response (UPR) and ER-associated degradation (ERAD). Resulting in the refolding of misfolded proteins and export of misfolded proteins from the ER to the ubiquitin proteasome system (UPS) for degradation, respectively. Long activation of the ER can cause pro-apoptotic consequences [87]. On the other hand, mutations in SOD1 impairs axonal transport. Therefore, misfolded SOD1 is not able to transport across the mitochondrial membranes and accumulates in the outer mitochondrial membrane, triggering the mitochondrial-dependent cell apoptosis program [88] (Figure 3A).

Pansarasa et al. identified a difference between protein expression and mRNA levels in wild-type SOD1 and sALS patients, and then proved their hypothesis on translocation and re-localization of the missing SOD1 in the nucleus. Furthermore, they found that the higher amounts of soluble SOD1 in the nucleus are positively correlated with a longer duration of disease, indicating a possible protective role of SOD1 [89]. Therefore, SOD1 can be considered as a good target for ALS therapy. In this perspective, 
riluzole, a sodium channel blocker and glutamate release inhibitor, has been applied to improve ALS symptoms and is approved by the FDA for treating ALS [90]. shRNA, miRNA, and RNAi have been evaluated for mediating SOD1 silencing in transgenic mice, which are under investigation for ALS treatment [91]. Moreover, SOD1-ALS patients show some features and clinical characteristics that are slightly different compared to other ALS patients such as earlier age of onset, longer duration of disease, and motor symptoms that begin more often in the lower limbs $[92,93]$.

\subsubsection{TARDBP}

In the 1990s, Leigh et al. concluded that neuronal cytoplasmic ubiquitinated inclusions were found in the spinal cord samples from ALS patients [94]. In 2006, TAR DNA-binding protein 43 (TDP-43) was discovered as the main reason for the protein aggregation in sALS cases $[57,95]$. Later, in 2008, several studies identified genetic variants in the TARDBP gene and the deviation of TDP-43 as a primary cause of ALS and neurodegeneration [26,96-99]. To date, over 40 variants have been identified in various ethnic groups with around $5 \%$ in fALS and up to $2 \%$ in sALS cases [100]. The majority of variants are missense variants located in the glycine-rich region at the transcript carboxy-terminal, which interacts with other heterogeneous ribonucleoproteins (Figure 5). The carboxy-terminal region is also involved in pre-mRNA splicing regulation $[57,101]$. Further studies on both fALS and sALS patients have shown the existence of TDP-43 in cytoplasmic aggregates of those without pathogenic variants in the TARDBP gene and carrying C9orf72 hexanucleotide repeat expansions [102-104].

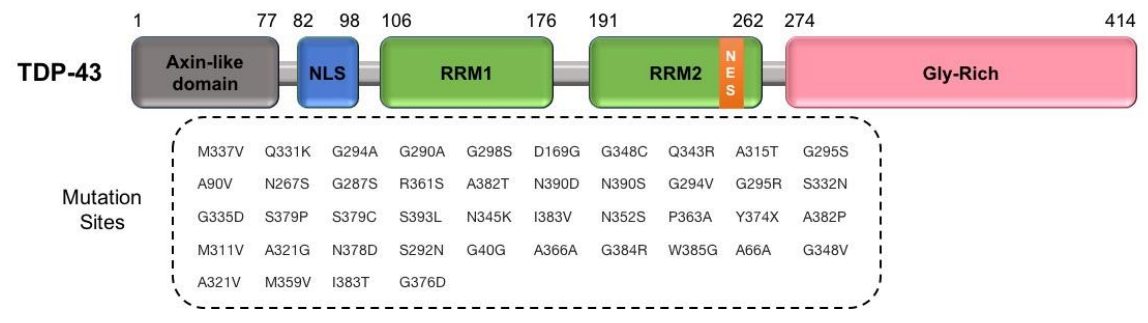

Figure 5. A scheme for exhibiting variants sites in TDP-43 protein: (Top) the TDP-43 domain structure; and (Bottom) the 44 TDP-43 variants shown in patients with ALS. NLS, nuclear localization signal; NES, nuclear export signal; RRM, RNA recognition motif.

TARDBP/TDP-43 is a DNA/RNA binding protein composed of 414 amino acids that are encoded by TARDBP/TDP43 gene. TDP-43 belongs to the ribonucleoprotein family and has various functions such as gene transcription, microRNA processing, RNA splicing and stabilization, and mRNA transport [105]. TDP-43 has both nuclear localization and export signals and continuously shuttles between the nucleus and cytoplasm $[106,107]$. Any interference in the normal intracellular trafficking of TDP-43 between the cytoplasm and nucleus can result in cytoplasmic aggregation and the loss of nuclear TDP-43 function in regulating transcription, splicing, and mRNA stability [108-110]. The challenging question about the role of TDP-43 in ALS is whether a toxic gain of function of cytoplasmic aggregates or a loss of its normal function in the nucleus is responsible for disease. During cellular stress, TDP-43 plays a significant role in controlling mRNA stability, translation, and nucleocytoplasmic transport [111]. In the case of ALS, while the loss of nuclear TDP-43 function leads to dysmorphic nuclear shape, deregulation of the cell cycle, and apoptosis [112], an overexpression of TDP-43 leads to abnormal mRNA accumulation in the nucleus, cytoplasmic accumulation $[113,114]$, and a lost normal functioning in the nucleus. Furthermore, the upregulation of cytoplasmic TDP- 43 forms the inclusion bodies and the capacity to propagate among cells as a "prion-like" protein, a significant reason for the neurodegeneration observed in motor neurons [115]. However, several studies used cultured cells, animal models, and patients autopsies, demonstrating how cytoplasmic TDP-43 aggregates have an important role in motor neuronal death and neurodegeneration observed in ALS patients $[115,116]$. Melamed et al. proposed that ALS is associated with loss of nuclear TDP-43 [117]. Their results confirm that reduction 
of nuclear TDP-43 inhibits regeneration of motor axons, which is the consequence of reduction in stathmin-2 (STMN2), an essential protein for axonal growth and maintenance (Figure 3B) $[117,118]$.

The discovery of TARDBP/TDP-43 and FUS, two RNA-binding proteins, highlights the importance of RNA processing in ALS pathogenesis. Previous studies have focused on understanding how exactly these mutant proteins disrupt RNA transcription and modification [119]. As expected, upregulation of TARDBP/TDP-43 in motor neurons increased ALS risk by altering RNA splicing and stability [120-122]. On the other hand, lack of TARDBP/TDP-43 in the forebrains of mice resulted in age-dependent brain atrophy by downregulating protein Tbc1d 1 in skeletal muscles, leading to compromised neuronal function [121,122]. In addition, Tsao et al. developed a Tardbp knockout mice model and showed a decrease in TARDBP/TDP-43 levels as well as a loss in body weight caused by an increase in fat oxidation and acceleration of fat loss in adipocytes [121]. Another study in Tardbp knock-in ALS mice indicated that mutant TDP-43 causes early-stage and dose-dependent motor neuron degeneration [123]. A recent study demonstrated that ALS patient-derived TARDBP/TDP-43 mutation at the carboxyl-terminal domain (M337V) causes splicing deregulation without motor neuronal degeneration in mice [124].

\subsubsection{FUS}

The next discovered gene that may rival the impact of TDP-43 on ALS research is the FUS gene (also known as TLS), which maps to the ALS6 locus on chromosome 16p11.2. Variants in the FUS gene are known to be causal for fALS [41,125]. The disease onset of ALS patients with ALS6 variants spans across a wide range of ages (from 26 to 80 years old) with a mean duration of around 33 months [80]. Over 70 variants in FUS have been identified in ALS patients, some of which have proved to be causal (Figure 6). ALS patients with FUS variants have a shorter life span, although extensive intrafamilial variability has been observed [126]. Waibel et al. showed two truncating FUS variants associated with consistent early onset and an aggressive disease course [127]. FUS variants have been reported to contribute $4 \%$ and $1 \%$ in fALS and sALS cases overall, respectively [128]. The most recent FUS variants were indicated as the most frequent cause of early-onset ALS (at ages less than 35 years) in German fALS patients with $8.7 \%$ frequency $[127,129]$.

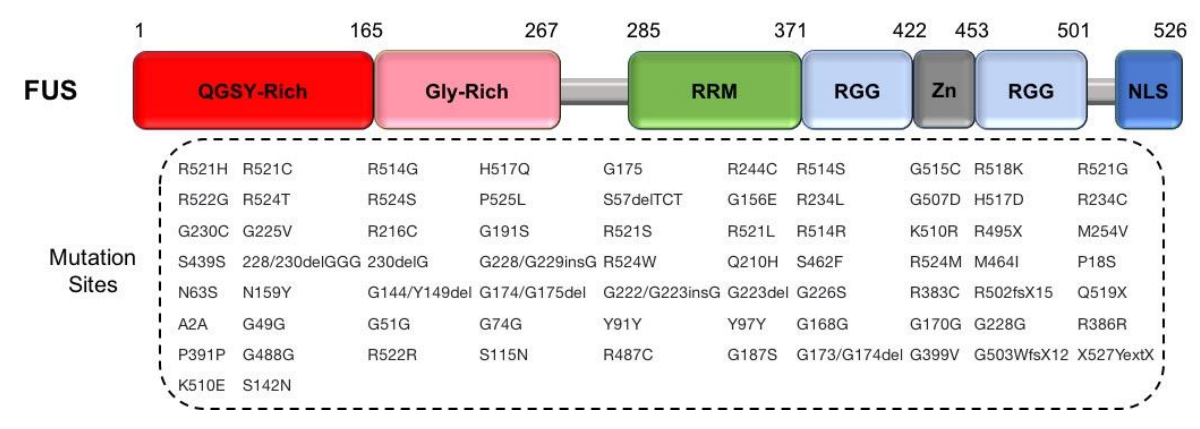

Figure 6. A scheme for exhibiting variants sites in FUS/TLS protein: (Top) the FUS domain structure; and (Bottom) the 72 FUS variants shown in patients with ALS. RGG, Arg-Gly-Gly.

FUS is an RNA binding protein encoded by a ubiquitously expressed gene and composed of 526 amino acids. FUS, EWSR1, and TAF15 belong to FET families, which are involved in transcription and alternative splicing by interacting with the transcription pre-initiation complex and various splicing factors. Under normal physiological conditions, FUS is mostly localized in the nucleus, but it shuttles to the cytoplasm and functions in nucleocytoplasmic transport [130]. Therefore, mutant FUS (mFUS) disrupts nucleocytoplasmic transport, leads to a depletion in the nucleus, aggregates in the cytoplasm, and causes neurotoxicity [131]. Mutant FUS binds to mature mRNAs in the cytoplasm, unlike WT FUS, which binds to precursor mRNAs. Abnormal binding of mFUS affects mRNA expression but has only modest expression changes. Mutant FUS not only suppresses global protein translation but also local protein translation, impairing the dendrites and axon terminals. Considering FUS 
as a part of RNA transport granules and its role in activated synapses [132,133], there would be defects in synaptic homeostasis and dysfunction in cells suffering from FUS mutations $[134,135]$. Diminishing of the proteins required for synaptic maintenance and function may lead to an ALS phenotype [136]. Furthermore, the gene binding profile has been altered in mFUS, which leads to neurotoxicity and mitochondrial size reduction due to disruption of the translation of transcripts associated with mitochondrial function [137] (Figure 3C).

In a study developed in 2015, while homozygous FUS knockout mice survived into adulthood, they had the phenotypes related to neuropsychiatric and neurodegenerative conditions, but different from ALS [138]. In further study, a model with conditionally removed FUS developed from the motor neurons of mice showed no significant effect on motor neuron survival or function. This suggests that a loss of FUS is not a sufficient cause for ALS [139]. However, Sasayama et al. found another layer of results when they used Drosophila FUS knockdown models [140]. They showed that decreasing the expression of Drosophila ortholog of FUS plays an important role in the degeneration of motoneurons and locomotive disability in the absence of abnormal cytoplasm aggregates. This suggests that the pathogenic mechanism of FUS-ALS can be considered as a loss of physiological FUS function in the nucleus rather than cytoplasmic FUS aggregate toxicity [140]. Moreover, mFUS transgenic rats developed progressive paralysis due to a loss of neurons in the cortex and hippocampus [141]. Later, Chen et al. showed that age-dependent progressive motor neurons were damaged when WT, R524S, or P525L mFUS were over-expressed in photoreceptors [142]. Recently, it was demonstrated that mFUS causes accumulation of NEAT1 isoforms and paraspeckles, which contribute to degenerating spinal motor neurons [143].

\subsubsection{Chromosome 9 Open Reading Frame 72 (C9orf72)}

Hexanucleotide repeat expansion (HRE), GGGGCC $\left(\mathrm{G}_{4} \mathrm{C}_{2}\right)$, in the non-coding region of the C9orf 72 gene was found as the most common inherited cause of ALS in European cohort in 2011 [45,144]. Renton et al. proposed that the $\mathrm{G}_{4} \mathrm{C}_{2} \mathrm{HRE}$ in the first intron on the affected haplotype in ALS patients is larger compared to healthy subjects (less than 30 HREs) [144,145] (Figure 7). However, increasing the repeat expansions is thought to be pathogenic. The exact cut-off between normal alleles and pathogenic expanded alleles is still unclear. In European cohorts, this HRE frequently occurs approximately in $40 \%$ and $7 \%$ of fALS and sALS, respectively, but is less frequent in Asian cohorts [24].

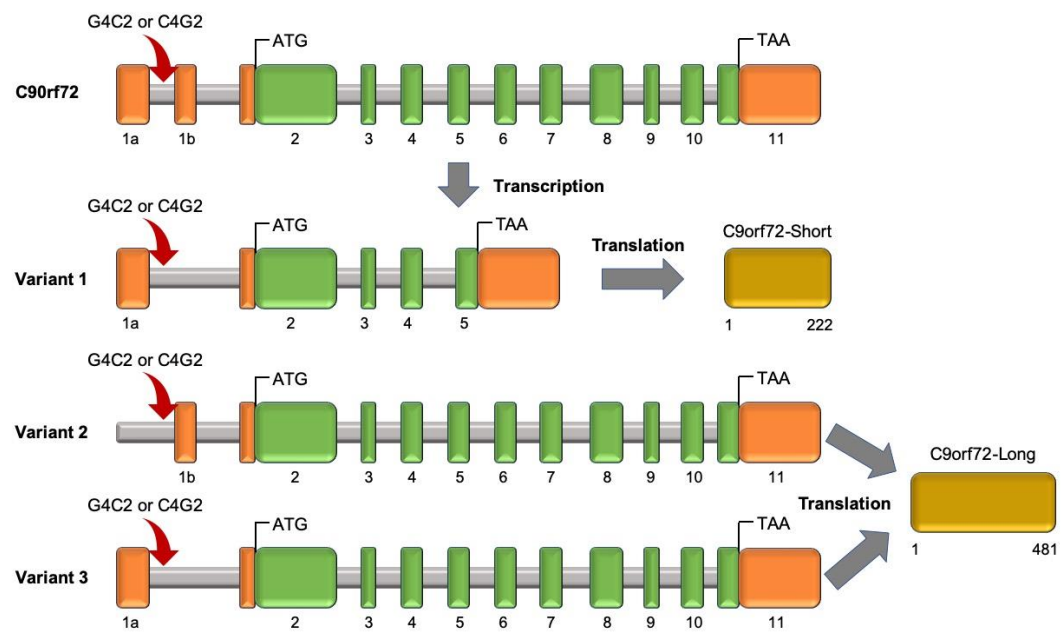

Figure 7. C9orf72 gene structure, transcript variants, and protein isoforms. The C9orf72 gene consists of 11 coding exons (green) and non-coding exons (orange). The G4C2 or C4G2 HRE is located in the first intron of variants 1 and 3 and within the promoter region of variant 2 . This figure was adapted from Balendra and Isaacs's study [146]. 
The known mechanisms for how HREs cause the disease can be categorized into two primary mechanisms [147]. First, mechanisms driving C9orf72 gain of function where RNAs containing G4C2 and C4G2 expanded repeats are bi-directionally transcribed and then aggregated in the cell nucleus. Dipeptide repeat proteins (DPRs) can be generated from repeat-containing RNAs that leave the nucleus. The imported DPRs into the nucleus can bind to the nucleolar proteins and cause nuclear stress [147-150]. On the other hand, RNA repeat-expansions can be retained in the nucleus and generate RNA foci, which has an important role in RNA-binding proteins, changes in RNA processing, nucleocytoplasmic transport impairment, and toxicity in the cell. C9orf72 RNA can sequester nucleolar proteins, bind to nuclear pore complex proteins, and disrupt nucleocytoplasmic transport. In addition, sequestration of RanGAP by the G4C2 RNA causes a reduction in the nuclear-cytoplasmic (N/C) distribution of Ran GTPase (Ran) and disrupts functional nucleocytoplasmic transport $[131,151]$. The nucleocytoplasmic trafficking correlated with mislocalization of TDP-43 in the cytoplasm. The second is C9orf72 loss-of-function mechanisms. In this mechanism, HRE leads to disrupted transcription, downregulation of $C 9$ orf 72 , and a loss of function. Previous studies showed the involvement of C9ORF72 in endosomal trafficking regulation as well as the inverse correlation between C9-isoform interactions with the nuclear pore complex and TDP-43 cytoplasmic inclusion levels. Then, a strong reduction of C9orf72 expression caused an inhibition of Shiga toxin transportation from the plasma membrane to the Golgi apparatus and altered expression of the autophagosome marker LC3 ratio $[152,153]$. Therefore, neurons from ALS patients with variants in C9orf72 have increased sensitivity to autophagy inhibition, suggesting that reductions in gene levels can lead to cellular distress [146] (Figure 3D).

In C9orf72-ALS patients, the age of onset is mostly between 30 and 70 years and bulbar onset has been more frequently observed [154]. Not only ALS and FTD but also parkinsonism and psychotic symptoms can be caused by C9orf72 expansions $[155,156]$. Considering the decreasing levels of C9orf72 mRNA and proteins in ALS patients with repeat expansions [157,158], Koppers et al. tested the validity of this hypothesis by developing a C9orf72 conditional knockout mouse model. However, evidence of motor neuron degeneration or motor deficits were unobserved [159]. A recent report case study highlights the phenotypic variability, including age of onset, within a family with the C9orf 72 repeat expansion [160].

\subsection{The Less Frequently Mutated Genes in ALS}

Nowadays, by developing next-generation sequencing technologies, rare genetic variants were discovered in several studies. However, the specific link between gene variants and disease mechanisms is sometimes unclear because of the small number of patients carrying those variants. Functions of the discovered genes can be categorized into four categories: (1) genes that influence RNA processing such as ANG [31], SETX [36], MATR3 [47], ATXN2 [30], TAF15 [161], EWSR1 [53,162], ELP3 [51], hnRNPa1, hnRNPA2B1 [29], ATXN1 [163], and GLE1 [164]; (2) genes involved in protein trafficking and degradation such as ALS2 [42], VAPB [43], CHMP2B [46], FIG4 [35], UBQLN2 [55], SQSTM1 [37], SIGMAR1 [33], OPTN [21], VCP [165] and TBK1 [166]; (3) genes that influence cytoskeletal and axonal dynamics such as DCTN1 [167], PFN1 [48], SPG11 [27], TUBA4A [50], NEFH [168], PRPH [49], NEK1 [169], C21orf2 [170]; and (4) CHCHD10 [171] and C19orf12 [172] involved in mitochondrial dysfunction.

\section{Conclusions}

Although we have come a long way since proposing SOD1 as the first ALS gene 27 years ago, the causative pathogenic mechanisms in ALS remain obscure. The function of mutant CYLD, S1R, GLT8D1, and KIF5A as the recently discovered genes involved in ALS pathogenesis is illustrated in Figure 2. In addition, Figure 3 provides previous findings of the genetic effects of mutant SOD1, TARDBP, FUS, and C9orf72 and the fundamental mechanisms of ALS pathogenesis. According to the genes and genetic functions reviewed in this paper, multiple factors are involved in ALS disease development and progression, in which the most commonly proposed ALS pathogenic mechanisms 
are RNA metabolism and protein metabolism. Furthermore, genetic and phenotypic variants between patients make it difficult to draw general conclusions on ALS pathogenesis and predict the future outcomes in ALS research. However, further research on finding novel genes, gene modifiers, and their molecular pathways might improve our understanding about this neurodegenerative disorder, which is still fatal. In addition, new therapeutic strategies, by either the identification of shared disease pathways or targeted therapies known for genetic variants can be developed by proposing novel ALS causal genes. As of now, riluzole is the only successfully established therapy for ALS that exerts transient effects on cortical and axonal hyperexcitability [173], whereas several drug trials targeting glutamatergic neurotransmission have been unsuccessful [174]. Regarding the irreversibility of genetic variants, developing therapeutic approaches is difficult and specific drugs that target the treatment of ALS are quite limited [175]. Considering how genetic variants result in epigenetic modifications and how epigenetic alterations are reversibly modulated in various neurodegenerative disorders such as Alzheimer's disease and Huntington's disease, it would be reasonable to design therapeutic approaches that target the epigenetic components to ameliorate the onset and symptoms of ALS [176-178]. Therefore, in future studies, a combination of treatments that modulate the multiple targets of epigenetic components could be the more effective therapeutic strategy for treating ALS.

Author Contributions: A.Y.-J. and H.R. wrote and revised the manuscript; Y.S. and J.K. contributed to drawing the figures; H.L.R. and J.L. edited the manuscript; and J.L. and H.R. read, reviewed, and approved the final manuscript. All authors have read and agreed to the published version of the manuscript.

Funding: This study was supported by NIH grants (R01AG054156 to H.R. and R01NS109537 to J.L.). This study was also supported by the National Research Foundation (NRF) grants (NRF-2016M3C7A1904233, NRF-2018M3C7A1056894, and 2020M3E5D9079742), the National Research Council of Science \& Technology (NST) grant (No. CRC-15-04-KIST) from Korea Ministry of Science, ICT and Future Planning (MSIP), and grants (2E30320 and 2E30762) from Korea Institute of Science and Technology of South Korea.

Acknowledgments: The authors would like to thank Joon-Yong An (Korea University, Seoul, Korea) for his kind advice and comments on collecting information for the genes variants.

Conflicts of Interest: The authors declare no conflict of interest.

\section{References}

1. Rowland, L.P.; Shneider, N.A. Amyotrophic lateral sclerosis. N. Engl. J. Med. 2001, 344, 1688-1700. [CrossRef]

2. Chio, A.; Logroscino, G.; Hardiman, O.; Swingler, R.; Mitchell, D.; Beghi, E.; Traynor, B.G. Prognostic factors in ALS: A critical review. Amyotroph. Lateral Scler. 2009, 10, 310-323. [CrossRef]

3. van Es, M.A.; Hardiman, O.; Chio, A.; Al-Chalabi, A.; Pasterkamp, R.J.; Veldink, J.H.; van den Berg, L.H. Amyotrophic lateral sclerosis. Lancet 2017, 390, 2084-2098. [CrossRef]

4. Petrov, D.; Mansfield, C.; Moussy, A.; Hermine, O. ALS Clinical Trials Review: 20 Years of Failure. Are We Any Closer to Registering a New Treatment? Front. Aging Neurosci. 2017, 9, 68. [CrossRef]

5. Hardiman, O.; Al-Chalabi, A.; Chio, A.; Corr, E.M.; Logroscino, G.; Robberecht, W.; Shaw, P.J; Simmons, Z.; van den Berg, L.H. Amyotrophic lateral sclerosis. Nat. Rev. Dis. Primers 2017, 3, 17071. [CrossRef]

6. Alsultan, A.A.; Waller, R.; Heath, P.R.; Kirby, J. The genetics of amyotrophic lateral sclerosis: Current insights. Degener. Neurol. Neuromuscul. Dis. 2016, 6, 49-64. [CrossRef]

7. Chen, S.; Sayana, P.; Zhang, X.; Le, W. Genetics of amyotrophic lateral sclerosis: An update. Mol. Neurodegener 2013, 8, 28. [CrossRef]

8. Iacoangeli, A.; Lin, T.; Al Khleifat, A.; Jones, A.R.; Opie-Martin, S.; Coleman, J.R.I; Shatunov, A.; Sproviero, W.; Williams, K.L.; Garton, F.; et al. Genome-wide Meta-analysis Finds the ACSL5-ZDHHC6 Locus Is Associated with ALS and Links Weight Loss to the Disease Genetics. Cell Rep. 2020, 33, 108323. [CrossRef]

9. Shatunov, A.; Al-Chalabi, A. The genetic architecture of ALS. Neurobiol. Dis. 2021, 147, 105156. [CrossRef]

10. Mejzini, R.; Flynn, L.L.; Pitout, I.L.; Fletcher, S.; Wilton, S.D.; Akkari, P.A. ALS Genetics, Mechanisms, and Therapeutics: Where Are We Now? Front. Neurosci. 2019, 13, 1310. [CrossRef]

11. Morgan, S.; Orrell, R.W. Pathogenesis of amyotrophic lateral sclerosis. Br. Med. Bull. 2016, 119, 87-98. [CrossRef]

12. Brenner, D.; Yilmaz, R.; Müller, K.; Grehl, T.; Petri, S.; Meyer, T.; Grosskreutz, J.; Weydt, P.; Ruf, W.; Neuwirth, C.; et al. Hot-spot KIF5A mutations cause familial ALS. Brain 2018, 141, 688-697. [CrossRef] 
13. Nicolas, A.; Kenna, K.P.; Renton, A.E.; Ticozzi, N.; Faghri, F.; Chia, R.; Dominov, J.A.; Kenna, B.J.; Nalls, M.A.; Keagle, P.; et al. Genome-wide Analyses Identify KIF5A as a Novel ALS Gene. Neuron 2018, 97, 1268-1283.e1266. [CrossRef]

14. Cooper-Knock, J.; Moll, T.; Ramesh, T.; Castelli, L.; Beer, A.; Robins, H.; Fox, I.; Niedermoser, I.; Van Damme, P.; Moisse, M.; et al. Mutations in the Glycosyltransferase Domain of GLT8D1 Are Associated with Familial Amyotrophic Lateral Sclerosis. Cell Rep. 2019, 26, 2298-2306.e2295. [CrossRef]

15. Couly, S.; Khalil, B.; Viguier, V.; Roussel, J.; Maurice, T.; Liévens, J.-C. Sigma-1 receptor is a key genetic modulator in amyotrophic lateral sclerosis. Hum. Mol. Genet. 2019, 29, 529-540. [CrossRef]

16. Dobson-Stone, C.; Hallupp, M.; Shahheydari, H.; Ragagnin, A.M.G.; Chatterton, Z.; Carew-Jones, F.; Shepherd, C.E.; Stefen, H.; Paric, E.; Fath, T.; et al. CYLD is a causative gene for frontotemporal dementia-Amyotrophic lateral sclerosis. Brain 2020, 143, 783-799. [CrossRef]

17. Farhan, S.M.K.; Howrigan, D.P.; Abbott, L.E.; Klim, J.R.; Topp, S.D.; Byrnes, A.E.; Churchhouse, C.; Phatnani, H.; Smith, B.N.; Rampersaud, E.; et al. Exome sequencing in amyotrophic lateral sclerosis implicates a novel gene, DNAJC7, encoding a heat-shock protein. Nat. Neurosci. 2019, 22, 1966-1974. [CrossRef]

18. Course, M.M.; Gudsnuk, K.; Smukowski, S.N.; Winston, K.; Desai, N.; Ross, J.P.; Sulovari, A.; Bourassa, C.V.; Spiegelman, D.; Couthouis, J.; et al. Evolution of a Human-Specific Tandem Repeat Associated with ALS. Am. J. Hum. Genet. 2020, 107, 445-460. [CrossRef]

19. Tazelaar, G.H.P.; Boeynaems, S.; De Decker, M.; van Vugt, J.J.F.A.; Kool, L.; Goedee, H.S.; McLaughlin, R.L.; Sproviero, W.; Iacoangeli, A.; Moisse, M.; et al. ATXN1 repeat expansions confer risk for amyotrophic lateral sclerosis and contribute to TDP-43 mislocalization. Brain Commun. 2020, 2. [CrossRef]

20. Nakamura, R.; Misawa, K.; Tohnai, G.; Nakatochi, M.; Furuhashi, S.; Atsuta, N.; Hayashi, N.; Yokoi, D.; Watanabe, H.; Watanabe, H.; et al. A multi-ethnic meta-analysis identifies novel genes, including ACSL5, associated with amyotrophic lateral sclerosis. Commun. Biol. 2020, 3, 526. [CrossRef]

21. Maruyama, H.; Morino, H.; Ito, H.; Izumi, Y.; Kato, H.; Watanabe, Y.; Kinoshita, Y.; Kamada, M.; Nodera, H.; Suzuki, H.; et al. Mutations of optineurin in amyotrophic lateral sclerosis. Nature 2010, 465, 223-226. [CrossRef] [PubMed]

22. Turner, M.R.; Hardiman, O.; Benatar, M.; Brooks, B.R.; Chio, A.; de Carvalho, M.; Ince, P.G.; Lin, C.; Miller, R.G.; Mitsumoto, H.; et al. Controversies and priorities in amyotrophic lateral sclerosis. Lancet Neurol. 2013, 12, 310-322. [CrossRef]

23. Haukedal, H.; Freude, K. Implications of Microglia in Amyotrophic Lateral Sclerosis and Frontotemporal Dementia. J. Mol. Biol. 2019, 431, 1818-1829. [CrossRef] [PubMed]

24. Zou, Z.Y.; Zhou, Z.R.; Che, C.H.; Liu, C.Y.; He, R.L.; Huang, H.P. Genetic epidemiology of amyotrophic lateral sclerosis: A systematic review and meta-analysis. J. Neurol Neurosurg. Psychiatry 2017, 88, 540-549. [CrossRef]

25. Cirulli, E.T.; Lasseigne, B.N.; Petrovski, S.; Sapp, P.C.; Dion, P.A.; Leblond, C.S.; Couthouis, J.; Lu, Y.-F.; Wang, Q.; Krueger, B.J.; et al. Exome sequencing in amyotrophic lateral sclerosis identifies risk genes and pathways. Science 2015, 347, 1436. [CrossRef]

26. Sreedharan, J.; Blair, I.P.; Tripathi, V.B.; Hu, X.; Vance, C.; Rogelj, B.; Ackerley, S.; Durnall, J.C.; Williams, K.L.; Buratti, E.; et al. TDP-43 mutations in familial and sporadic amyotrophic lateral sclerosis. Science 2008, 319, 1668-1672. [CrossRef]

27. Orlacchio, A.; Babalini, C.; Borreca, A.; Patrono, C.; Massa, R.; Basaran, S.; Munhoz, R.P.; Rogaeva, E.A.; St George-Hyslop, P.H.; Bernardi, G.; et al. SPATACSIN mutations cause autosomal recessive juvenile amyotrophic lateral sclerosis. Brain 2010, 133, 591-598. [CrossRef]

28. Johnson, J.O.; Mandrioli, J.; Benatar, M.; Abramzon, Y.; Van Deerlin, V.M.; Trojanowski, J.Q.; Gibbs, J.R.; Brunetti, M.; Gronka, S.; Wuu, J.; et al. Exome sequencing reveals VCP mutations as a cause of familial ALS. Neuron 2010, 68, 857-864. [CrossRef]

29. Kim, H.J.; Kim, N.C.; Wang, Y.-D.; Scarborough, E.A.; Moore, J.; Diaz, Z.; MacLea, K.S.; Freibaum, B.; Li, S.; Molliex, A.; et al. Mutations in prion-like domains in hnRNPA2B1 and hnRNPA1 cause multisystem proteinopathy and ALS. Nature 2013, 495, 467-473. [CrossRef]

30. Elden, A.C.; Kim, H.-J.; Hart, M.P.; Chen-Plotkin, A.S.; Johnson, B.S.; Fang, X.; Armakola, M.; Geser, F.; Greene, R.; Lu, M.M.; et al. Ataxin-2 intermediate-length polyglutamine expansions are associated with increased risk for ALS. Nature 2010, 466, 1069-1075. [CrossRef] 
31. Greenway, M.J.; Andersen, P.M.; Russ, C.; Ennis, S.; Cashman, S.; Donaghy, C.; Patterson, V.; Swingler, R.; Kieran, D.; Prehn, J.; et al. ANG mutations segregate with familial and 'sporadic' amyotrophic lateral sclerosis. Nat. Genet. 2006, 38, 411-413. [CrossRef] [PubMed]

32. Project MinE ALS Sequencing Consortium. CHCHD10 variants in amyotrophic lateral sclerosis: Where is the evidence? Ann. Neurol. 2018, 84, 110-116. [CrossRef] [PubMed]

33. Luty, A.A.; Kwok, J.B.J.; Dobson-Stone, C.; Loy, C.T.; Coupland, K.G.; Karlström, H.; Sobow, T.; Tchorzewska, J.; Maruszak, A.; Barcikowska, M.; et al. Sigma nonopioid intracellular receptor 1 mutations cause frontotemporal lobar degeneration-motor neuron disease. Ann. Neurol. 2010, 68, 639-649. [CrossRef] [PubMed]

34. Al-Saif, A.; Al-Mohanna, F.; Bohlega, S. A mutation in sigma-1 receptor causes juvenile amyotrophic lateral sclerosis. Ann. Neurol. 2011, 70, 913-919. [CrossRef]

35. Chow, C.Y.; Landers, J.E.; Bergren, S.K.; Sapp, P.C.; Grant, A.E.; Jones, J.M.; Everett, L.; Lenk, G.M.; McKenna-Yasek, D.M.; Weisman, L.S.; et al. Deleterious Variants of FIG4, a Phosphoinositide Phosphatase, in Patients with ALS. Am. J. Hum. Genet. 2009, 84, 85-88. [CrossRef]

36. Chen, Y.-Z.; Bennett, C.L.; Huynh, H.M.; Blair, I.P.; Puls, I.; Irobi, J.; Dierick, I.; Abel, A.; Kennerson, M.L.; Rabin, B.A.; et al. DNA/RNA Helicase Gene Mutations in a Form of Juvenile Amyotrophic Lateral Sclerosis (ALS4). Am. J. Hum. Genet. 2004, 74, 1128-1135. [CrossRef]

37. Fecto, F.; Yan, J.; Vemula, S.P.; Liu, E.; Yang, Y.; Chen, W.; Zheng, J.G.; Shi, Y.; Siddique, N.; Arrat, H.; et al. SQSTM1 Mutations in Familial and Sporadic Amyotrophic Lateral Sclerosis. Arch. Neurol. 2011, 68, 1440-1446. [CrossRef]

38. Freischmidt, A.; Wieland, T.; Richter, B.; Ruf, W.; Schaeffer, V.; Müller, K.; Marroquin, N.; Nordin, F.; Hübers, A.; Weydt, P.; et al. Haploinsufficiency of TBK1 causes familial ALS and fronto-temporal dementia. Nat. Neurosci. 2015, 18, 631-636. [CrossRef]

39. Kenna, K.P.; van Doormaal, P.T.C.; Dekker, A.M.; Ticozzi, N.; Kenna, B.J.; Diekstra, F.P.; van Rheenen, W.; van Eijk, K.R.; Jones, A.R.; Keagle, P.; et al. NEK1 variants confer susceptibility to amyotrophic lateral sclerosis. Nat. Genet. 2016, 48, 1037-1042. [CrossRef]

40. Ticozzi, N.; Vance, C.; Leclerc, A.L.; Keagle, P.; Glass, J.D.; McKenna-Yasek, D.; Sapp, P.C.; Silani, V.; Bosco, D.A.; Shaw, C.E.; et al. Mutational analysis reveals the FUS homolog TAF15 as a candidate gene for familial amyotrophic lateral sclerosis. Am. J. Med. Genet. B Neuropsychiatr. Genet. 2011, 156b, 285-290. [CrossRef]

41. Kwiatkowski, T.J., Jr.; Bosco, D.A.; Leclerc, A.L.; Tamrazian, E.; Vanderburg, C.R.; Russ, C.; Davis, A.; Gilchrist, J.; Kasarskis, E.J.; Munsat, T.; et al. Mutations in the FUS/TLS gene on chromosome 16 cause familial amyotrophic lateral sclerosis. Science 2009, 323, 1205-1208. [CrossRef] [PubMed]

42. Hadano, S.; Hand, C.K.; Osuga, H.; Yanagisawa, Y.; Otomo, A.; Devon, R.S.; Miyamoto, N.; Showguchi-Miyata, J.; Okada, Y.; Singaraja, R.; et al. A gene encoding a putative GTPase regulator is mutated in familial amyotrophic lateral sclerosis 2. Nat. Genet. 2001, 29, 166-173. [CrossRef] [PubMed]

43. Nishimura, A.L.; Mitne-Neto, M.; Silva, H.C.A.; Richieri-Costa, A.; Middleton, S.; Cascio, D.; Kok, F.; Oliveira, J.R.M.; Gillingwater, T.; Webb, J.; et al. A Mutation in the Vesicle-Trafficking Protein VAPB Causes Late-Onset Spinal Muscular Atrophy and Amyotrophic Lateral Sclerosis. Am. J. Hum. Genet. 2004, 75, 822-831. [CrossRef] [PubMed]

44. Al-Chalabi, A.; Andersen, P.M.; Nilsson, P.; Chioza, B.; Andersson, J.L.; Russ, C.; Shaw, C.E.; Powell, J.F.; Nigel Leigh, P. Deletions of the Heavy Neurofilament Subunit Tail in Amyotrophic Lateral Sclerosis. Hum. Mol. Genet. 1999, 8, 157-164. [CrossRef]

45. DeJesus-Hernandez, M.; Mackenzie, I.R.; Boeve, B.F.; Boxer, A.L.; Baker, M.; Rutherford, N.J.; Nicholson, A.M.; Finch, N.A.; Flynn, H.; Adamson, J.; et al. Expanded GGGGCC hexanucleotide repeat in noncoding region of C9ORF72 causes chromosome 9p-linked FTD and ALS. Neuron 2011, 72, 245-256. [CrossRef]

46. Parkinson, N.; Ince, P.G.; Smith, M.O.; Highley, R.; Skibinski, G.; Andersen, P.M.; Morrison, K.E.; Pall, H.S.; Hardiman, O.; Collinge, J.; et al. ALS phenotypes with mutations in CHMP2B (charged multivesicular body protein 2B). Neurology 2006, 67, 1074-1077. [CrossRef]

47. Johnson, J.O.; Pioro, E.P.; Boehringer, A.; Chia, R.; Feit, H.; Renton, A.E.; Pliner, H.A.; Abramzon, Y.; Marangi, G.; Winborn, B.J.; et al. Mutations in the Matrin 3 gene cause familial amyotrophic lateral sclerosis. Nat. Neurosci. 2014, 17, 664-666. [CrossRef] 
48. Wu, C.-H.; Fallini, C.; Ticozzi, N.; Keagle, P.J.; Sapp, P.C.; Piotrowska, K.; Lowe, P.; Koppers, M.; McKenna-Yasek, D.; Baron, D.M.; et al. Mutations in the profilin 1 gene cause familial amyotrophic lateral sclerosis. Nature 2012, 488, 499-503. [CrossRef]

49. Gros-Louis, F.; Larivière, R.; Gowing, G.; Laurent, S.; Camu, W.; Bouchard, J.P.; Meininger, V.; Rouleau, G.A.; Julien, J.P. A frameshift deletion in peripherin gene associated with amyotrophic lateral sclerosis. J. Biol. Chem. 2004, 279, 45951-45956. [CrossRef]

50. Smith, B.N.; Ticozzi, N.; Fallini, C.; Gkazi, A.S.; Topp, S.; Kenna, K.P.; Scotter, E.L.; Kost, J.; Keagle, P.; Miller, J.W.; et al. Exome-wide Rare Variant Analysis Identifies TUBA4A Mutations Associated with Familial ALS. Neuron 2014, 84, 324-331. [CrossRef]

51. Simpson, C.L.; Lemmens, R.; Miskiewicz, K.; Broom, W.J.; Hansen, V.K.; van Vught, P.W.J.; Landers, J.E.; Sapp, P.; Van Den Bosch, L.; Knight, J.; et al. Variants of the elongator protein 3 ( ELP3 ) gene are associated with motor neuron degeneration. Hum. Mol. Genet. 2008, 18, 472-481. [CrossRef] [PubMed]

52. Puls, I.; Jonnakuty, C.; LaMonte, B.H.; Holzbaur, E.L.F.; Tokito, M.; Mann, E.; Floeter, M.K.; Bidus, K.; Drayna, D.; Oh, S.J.; et al. Mutant dynactin in motor neuron disease. Nat. Genet. 2003, 33, 455-456. [CrossRef] [PubMed]

53. Couthouis, J.; Hart, M.P.; Erion, R.; King, O.D.; Diaz, Z.; Nakaya, T.; Ibrahim, F.; Kim, H.-J.; Mojsilovic-Petrovic, J.; Panossian, S.; et al. Evaluating the role of the FUS/TLS-related gene EWSR1 in amyotrophic lateral sclerosis. Hum. Mol. Genet. 2012, 21, 2899-2911. [CrossRef] [PubMed]

54. Kaneb, H.M.; Folkmann, A.W.; Belzil, V.V.; Jao, L.-E.; Leblond, C.S.; Girard, S.L.; Daoud, H.; Noreau, A.; Rochefort, D.; Hince, P.; et al. Deleterious mutations in the essential mRNA metabolism factor, hGle1, in amyotrophic lateral sclerosis. Hum. Mol. Genet. 2015, 24, 1363-1373. [CrossRef] [PubMed]

55. Deng, H.-X.; Chen, W.; Hong, S.-T.; Boycott, K.M.; Gorrie, G.H.; Siddique, N.; Yang, Y.; Fecto, F.; Shi, Y.; Zhai, H.; et al. Mutations in UBQLN2 cause dominant X-linked juvenile and adult-onset ALS and ALS/dementia. Nature 2011, 477, 211-215. [CrossRef] [PubMed]

56. Dobson-Stone, C.; Luty, A.A.; Thompson, E.M.; Blumbergs, P.; Brooks, W.S.; Short, C.L.; Field, C.D.; Panegyres, P.K.; Hecker, J.; Solski, J.A.; et al. Frontotemporal dementia-amyotrophic lateral sclerosis syndrome locus on chromosome 16p12.1-q12.2: Genetic, clinical and neuropathological analysis. Acta Neuropathol. 2013, 125, 523-533. [CrossRef]

57. Neumann, M.; Sampathu, D.M.; Kwong, L.K.; Truax, A.C.; Micsenyi, M.C.; Chou, T.T.; Bruce, J.; Schuck, T.; Grossman, M.; Clark, C.M.; et al. Ubiquitinated TDP-43 in frontotemporal lobar degeneration and amyotrophic lateral sclerosis. Science 2006, 314, 130-133. [CrossRef]

58. Evans, C.S.; Holzbaur, E.L.F. Autophagy and mitophagy in ALS. Neurobiol. Dis. 2019, 122, 35-40. [CrossRef]

59. Deng, Z.; Sheehan, P.; Chen, S.; Yue, Z. Is amyotrophic lateral sclerosis/frontotemporal dementia an autophagy disease? Mol. Neurodegener. 2017, 12, 90. [CrossRef]

60. Budini, M.; Buratti, E.; Morselli, E.; Criollo, A. Autophagy and Its Impact on Neurodegenerative Diseases: New Roles for TDP-43 and C9orf72. Front. Mol. Neurosci. 2017, 10. [CrossRef]

61. Tesei, A.; Cortesi, M.; Zamagni, A.; Arienti, C.; Pignatta, S.; Zanoni, M.; Paolillo, M.; Curti, D.; Rui, M.; Rossi, D.; et al. Sigma Receptors as Endoplasmic Reticulum Stress "Gatekeepers" and their Modulators as Emerging New Weapons in the Fight Against Cancer. Front. Pharmacol. 2018, 9, 711. [CrossRef] [PubMed]

62. Wang, L.; Lim, L.; Dang, M.; Song, J. A novel mechanism for ATP to enhance the functional oligomerization of TDP-43 by specific binding. Biochem. Biophys. Res. Commun. 2019, 514, 809-814. [CrossRef] [PubMed]

63. Bernard-Marissal, N.; Médard, J.J.; Azzedine, H.; Chrast, R. Dysfunction in endoplasmic reticulum-mitochondria crosstalk underlies SIGMAR1 loss of function mediated motor neuron degeneration. Brain 2015, 138, 875-890. [CrossRef] [PubMed]

64. Mavlyutov, T.A.; Guo, L.-W.; Epstein, M.L.; Ruoho, A.E. Role of the Sigma-1 receptor in Amyotrophic Lateral Sclerosis (ALS). J. Pharmacol. Sci. 2015, 127, 10-16. [CrossRef] [PubMed]

65. Li, W.; Liu, Z.; Sun, W.; Yuan, Y.; Hu, Y.; Ni, J.; Jiao, B.; Fang, L.; Li, J.; Shen, L.; et al. Mutation analysis of GLT8D1 and ARPP21 genes in amyotrophic lateral sclerosis patients from mainland China. Neurobiol. Aging 2020, 85, 156.e151-156.e154. [CrossRef] [PubMed]

66. d'Azzo, A.; Tessitore, A.; Sano, R. Gangliosides as apoptotic signals in ER stress response. Cell Death Differ. 2006, 13, 404-414. [CrossRef] [PubMed]

67. Yu, R.K.; Tsai, Y.-T.; Ariga, T. Functional Roles of Gangliosides in Neurodevelopment: An Overview of Recent Advances. Neurochem. Res. 2012, 37, 1230-1244. [CrossRef] 
68. Moll, T.; Shaw, P.J.; Cooper-Knock, J. Disrupted glycosylation of lipids and proteins is a cause of neurodegeneration. Brain A J. Neurol. 2020, 143, 1332-1340. [CrossRef]

69. Simone, M.; Trabacca, A.; Panzeri, E.; Losito, L.; Citterio, A.; Bassi, M.T. KIF5A and ALS2 Variants in a Family With Hereditary Spastic Paraplegia and Amyotrophic Lateral Sclerosis. Front. Neurol. 2018, 9. [CrossRef]

70. Nakamura, R.; Tohnai, G.; Atsuta, N.; Nakatochi, M.; Hayashi, N.; Watanabe, H.; Yokoi, D.; Watanabe, H.; Katsuno, M.; Izumi, Y.; et al. Genetic and functional analysis of KIF5A variants in Japanese patients with sporadic amyotrophic lateral sclerosis. Neurobiol. Aging 2020. [CrossRef]

71. Chevalier-Larsen, E.; Holzbaur, E.L.F. Axonal transport and neurodegenerative disease. Biochim. Biophys. Acta BBA Mol. Basis Dis. 2006, 1762, 1094-1108. [CrossRef] [PubMed]

72. Hirokawa, N.; Niwa, S.; Tanaka, Y. Molecular Motors in Neurons: Transport Mechanisms and Roles in Brain Function, Development, and Disease. Neuron 2010, 68, 610-638. [CrossRef] [PubMed]

73. Millecamps, S.; Julien, J.-P. Axonal transport deficits and neurodegenerative diseases. Nat. Rev. Neurosci. 2013, 14, 161-176. [CrossRef] [PubMed]

74. Kanai, Y.; Dohmae, N.; Hirokawa, N. Kinesin Transports RNA: Isolation and Characterization of an RNA-Transporting Granule. Neuron 2004, 43, 513-525. [CrossRef] [PubMed]

75. Rosen, D.R.; Siddique, T.; Patterson, D.; Figlewicz, D.A.; Sapp, P.; Hentati, A.; Donaldson, D.; Goto, J.; O'Regan, J.P.; Deng, H.X.; et al. Mutations in $\mathrm{Cu} / \mathrm{Zn}$ superoxide dismutase gene are associated with familial amyotrophic lateral sclerosis. Nature 1993, 362, 59-62. [CrossRef]

76. Park, J.H.; Elpers, C.; Reunert, J.; McCormick, M.L.; Mohr, J.; Biskup, S.; Schwartz, O.; Rust, S.; Grüneberg, M.; Seelhöfer, A.; et al. SOD1 deficiency: A novel syndrome distinct from amyotrophic lateral sclerosis. Brain 2019, 142, 2230-2237. [CrossRef]

77. Huai, J.; Zhang, Z. Structural Properties and Interaction Partners of Familial ALS-Associated SOD1 Mutants. Front. Neurol. 2019, 10. [CrossRef]

78. Yamashita, S.; Ando, Y. Genotype-phenotype relationship in hereditary amyotrophic lateral sclerosis. Transl. Neurodegener. 2015, 4, 13. [CrossRef]

79. Abel, O.; Powell, J.F.; Andersen, P.M.; Al-Chalabi, A. ALSoD: A user-friendly online bioinformatics tool for amyotrophic lateral sclerosis genetics. Hum. Mutat. 2012, 33, 1345-1351. [CrossRef]

80. Pasinelli, P.; Brown, R.H. Molecular biology of amyotrophic lateral sclerosis: Insights from genetics. Nat. Rev. Neurosci. 2006, 7, 710-723. [CrossRef]

81. Azadmanesh, J.; Borgstahl, G.E.O. A Review of the Catalytic Mechanism of Human Manganese Superoxide Dismutase. Antioxidants 2018, 7, 25. [CrossRef] [PubMed]

82. Kaur, S.J.; McKeown, S.R.; Rashid, S. Mutant SOD1 mediated pathogenesis of Amyotrophic Lateral Sclerosis. Gene 2016, 577, 109-118. [CrossRef] [PubMed]

83. Julien, J.P. Amyotrophic lateral sclerosis. Unfolding the toxicity of the misfolded. Cell 2001, 104, 581-591. [CrossRef]

84. Hayashi, Y.; Homma, K.; Ichijo, H. SOD1 in neurotoxicity and its controversial roles in SOD1 mutation-negative ALS. Adv. Biol. Regul. 2016, 60, 95-104. [CrossRef]

85. Boillée, S.; Vande Velde, C.; Cleveland, D.W. ALS: A Disease of Motor Neurons and Their Nonneuronal Neighbors. Neuron 2006, 52, 39-59. [CrossRef]

86. Paré, B.; Lehmann, M.; Beaudin, M.; Nordström, U.; Saikali, S.; Julien, J.-P.; Gilthorpe, J.D.; Marklund, S.L.; Cashman, N.R.; Andersen, P.M.; et al. Misfolded SOD1 pathology in sporadic Amyotrophic Lateral Sclerosis. Sci. Rep. 2018, 8, 14223. [CrossRef]

87. Bunton-Stasyshyn, R.K.; Saccon, R.A.; Fratta, P.; Fisher, E.M. SOD1 Function and Its Implications for Amyotrophic Lateral Sclerosis Pathology: New and Renascent Themes. Neuroscientist 2015, 21, 519-529. [CrossRef]

88. Tafuri, F.; Ronchi, D.; Magri, F.; Comi, G.P.; Corti, S. SOD1 misplacing and mitochondrial dysfunction in amyotrophic lateral sclerosis pathogenesis. Front. Cell. Neurosci. 2015, 9, 336. [CrossRef]

89. Pansarasa, O.; Bordoni, M.; Diamanti, L.; Sproviero, D.; Gagliardi, S.; Cereda, C. SOD1 in Amyotrophic Lateral Sclerosis: "Ambivalent" Behavior Connected to the Disease. Int. J. Mol. Sci. 2018, 19, 1345. [CrossRef]

90. Mathis, S.; Couratier, P.; Julian, A.; Vallat, J.M.; Corcia, P.; Le Masson, G. Management and therapeutic perspectives in amyotrophic lateral sclerosis. Expert Rev. Neurother. 2017, 17, 263-276. [CrossRef]

91. Jain, K.K. Neuroprotection in Amyotrophic Lateral Sclerosis. In The Handbook of Neuroprotection; Jain, K.K., Ed.; Springer: New York, NY, USA, 2019. 
92. Andersen, P.M.; Nilsson, P.; Keranen, M.L.; Forsgren, L.; Hagglund, J.; Karlsborg, M.; Ronnevi, L.O.; Gredal, O.; Marklund, S.L. Phenotypic heterogeneity in motor neuron disease patients with CuZn-superoxide dismutase mutations in Scandinavia. Brain 1997, 120, 1723-1737. [CrossRef] [PubMed]

93. Corcia, P.; Valdmanis, P.; Millecamps, S.; Lionnet, C.; Blasco, H.; Mouzat, K.; Daoud, H.; Belzil, V.; Morales, R.; Pageot, N.; et al. Phenotype and genotype analysis in amyotrophic lateral sclerosis with TARDBP gene mutations. Neurology 2012, 78, 1519-1526. [CrossRef] [PubMed]

94. Leigh, P.N.; Whitwell, H.; Garofalo, O.; Buller, J.; Swash, M.; Martin, J.E.; Gallo, J.M.; Weller, R.O.; Anderton, B.H. Ubiquitin-immunoreactive intraneuronal inclusions in amyotrophic lateral sclerosis. Morphology, distribution, and specificity. Brain 1991, 114, 775-788. [CrossRef] [PubMed]

95. Arai, T.; Hasegawa, M.; Akiyama, H.; Ikeda, K.; Nonaka, T.; Mori, H.; Mann, D.; Tsuchiya, K.; Yoshida, M.; Hashizume, Y.; et al. TDP-43 is a component of ubiquitin-positive tau-negative inclusions in frontotemporal lobar degeneration and amyotrophic lateral sclerosis. Biochem. Biophys. Res. Commun. 2006, 351, 602-611. [CrossRef] [PubMed]

96. Gitcho, M.A.; Baloh, R.H.; Chakraverty, S.; Mayo, K.; Norton, J.B.; Levitch, D.; Hatanpaa, K.J.; White, C.L., 3rd; Bigio, E.H.; Caselli, R.; et al. TDP-43 A315T mutation in familial motor neuron disease. Ann. Neurol 2008, 63, 535-538. [CrossRef] [PubMed]

97. Kabashi, E.; Valdmanis, P.N.; Dion, P.; Spiegelman, D.; McConkey, B.J.; Vande Velde, C.; Bouchard, J.P.; Lacomblez, L.; Pochigaeva, K.; Salachas, F.; et al. TARDBP mutations in individuals with sporadic and familial amyotrophic lateral sclerosis. Nat. Genet. 2008, 40, 572-574. [CrossRef]

98. Van Deerlin, V.M.; Leverenz, J.B.; Bekris, L.M.; Bird, T.D.; Yuan, W.; Elman, L.B.; Clay, D.; Wood, E.M.; Chen-Plotkin, A.S.; Martinez-Lage, M.; et al. TARDBP mutations in amyotrophic lateral sclerosis with TDP-43 neuropathology: A genetic and histopathological analysis. Lancet Neurol. 2008, 7, 409-416. [CrossRef]

99. Yokoseki, A.; Shiga, A.; Tan, C.F.; Tagawa, A.; Kaneko, H.; Koyama, A.; Eguchi, H.; Tsujino, A.; Ikeuchi, T.; Kakita, A.; et al. TDP-43 mutation in familial amyotrophic lateral sclerosis. Ann. Neurol. 2008, 63, 538-542. [CrossRef]

100. Lattante, S.; Rouleau, G.A.; Kabashi, E. TARDBP and FUS mutations associated with amyotrophic lateral sclerosis: Summary and update. Hum. Mutat. 2013, 34, 812-826. [CrossRef]

101. Buratti, E.; Brindisi, A.; Giombi, M.; Tisminetzky, S.; Ayala, Y.M.; Baralle, F.E. TDP-43 binds heterogeneous nuclear ribonucleoprotein A/B through its C-terminal tail: An important region for the inhibition of cystic fibrosis transmembrane conductance regulator exon 9 splicing. J. Biol. Chem. 2005, 280, 37572-37584. [CrossRef]

102. Giordana, M.T.; Piccinini, M.; Grifoni, S.; De Marco, G.; Vercellino, M.; Magistrello, M.; Pellerino, A.; Buccinna, B.; Lupino, E.; Rinaudo, M.T. TDP-43 redistribution is an early event in sporadic amyotrophic lateral sclerosis. Brain Pathol. 2010, 20, 351-360. [CrossRef] [PubMed]

103. Schipper, L.J.; Raaphorst, J.; Aronica, E.; Baas, F.; de Haan, R.; de Visser, M.; Troost, D. Prevalence of brain and spinal cord inclusions, including dipeptide repeat proteins, in patients with the C9ORF72 hexanucleotide repeat expansion: A systematic neuropathological review. Neuropathol. Appl. Neurobiol. 2016, 42, 547-560. [CrossRef] [PubMed]

104. Takeuchi, R.; Tada, M.; Shiga, A.; Toyoshima, Y.; Konno, T.; Sato, T.; Nozaki, H.; Kato, T.; Horie, M.; Shimizu, H.; et al. Heterogeneity of cerebral TDP-43 pathology in sporadic amyotrophic lateral sclerosis: Evidence for clinico-pathologic subtypes. Acta Neuropathol. Commun. 2016, 4, 61. [CrossRef] [PubMed]

105. Buratti, E.; Baralle, F.E. The multiple roles of TDP-43 in pre-mRNA processing and gene expression regulation. RNA Biol. 2010, 7, 420-429. [CrossRef] [PubMed]

106. Ayala, Y.M.; Zago, P.; D’Ambrogio, A.; Xu, Y.F.; Petrucelli, L.; Buratti, E.; Baralle, F.E. Structural determinants of the cellular localization and shuttling of TDP-43. J. Cell Sci. 2008, 121, 3778-3785. [CrossRef]

107. Ratti, A.; Buratti, E. Physiological functions and pathobiology of TDP-43 and FUS/TLS proteins. J. Neurochem 2016, 138, 95-111. [CrossRef]

108. Winton, M.J.; Igaz, L.M.; Wong, M.M.; Kwong, L.K.; Trojanowski, J.Q.; Lee, V.M.Y. Disturbance of nuclear and cytoplasmic TAR DNA-binding protein (TDP-43) induces disease-like redistribution, sequestration, and aggregate formation. J. Biol. Chem. 2008, 283, 13302-13309. [CrossRef]

109. Buratti, E.; Baralle, F.E. Multiple roles of TDP-43 in gene expression, splicing regulation, and human disease. Front. Biosci. 2008, 13, 867-878. [CrossRef] 
110. Strong, M.J.; Volkening, K.; Hammond, R.; Yang, W.; Strong, W.; Leystra-Lantz, C.; Shoesmith, C. TDP43 is a human low molecular weight neurofilament (hNFL) mRNA-binding protein. Mol. Cell Neurosci. 2007, 35, 320-327. [CrossRef]

111. Zhao, M.; Kim, J.R.; van Bruggen, R.; Park, J. RNA-Binding Proteins in Amyotrophic Lateral Sclerosis. Mol. Cells 2018, 41, 818-829. [CrossRef]

112. Ayala, Y.M.; Misteli, T.; Baralle, F.E. TDP-43 regulates retinoblastoma protein phosphorylation through the repression of cyclin-dependent kinase 6 expression. Proc. Natl. Acad. Sci. USA 2008, 105, 3785-3789. [CrossRef] [PubMed]

113. Woerner, A.C.; Frottin, F.; Hornburg, D.; Feng, L.R.; Meissner, F.; Patra, M.; Tatzelt, J.; Mann, M.; Winklhofer, K.F.; Hartl, F.U.; et al. Cytoplasmic protein aggregates interfere with nucleocytoplasmic transport of protein and RNA. Science 2016, 351, 173-176. [CrossRef] [PubMed]

114. Butti, Z.; Patten, S.A. RNA Dysregulation in Amyotrophic Lateral Sclerosis. Front. Genet. $2019,9,712$. [CrossRef] [PubMed]

115. Hergesheimer, R.C.; Chami, A.A.; de Assis, D.R.; Vourc'h, P.; Andres, C.R.; Corcia, P.; Lanznaster, D.; Blasco, $\mathrm{H}$. The debated toxic role of aggregated TDP-43 in amyotrophic lateral sclerosis: A resolution in sight? Brain A J. Neurol. 2019, 142, 1176-1194. [CrossRef]

116. Prasad, A.; Bharathi, V.; Sivalingam, V.; Girdhar, A.; Patel, B.K. Molecular Mechanisms of TDP-43 Misfolding and Pathology in Amyotrophic Lateral Sclerosis. Front. Mol. Neurosci. 2019, 12. [CrossRef]

117. Melamed, Z.E.; López-Erauskin, J.; Baughn, M.W.; Zhang, O.; Drenner, K.; Sun, Y.; Freyermuth, F.; McMahon, M.A.; Beccari, M.S.; Artates, J.W.; et al. Premature polyadenylation-mediated loss of stathmin-2 is a hallmark of TDP-43-dependent neurodegeneration. Nat. Neurosci. 2019, 22, 180-190. [CrossRef]

118. Prudencio, M.; Humphrey, J.; Pickles, S.; Brown, A.-L.; Hill, S.E.; Kachergus, J.M.; Shi, J.; Heckman, M.G.; Spiegel, M.R.; Cook, C.; et al. Truncated stathmin-2 is a marker of TDP-43 pathology in frontotemporal dementia. J. Clin. Investig. 2020, 130, 6080-6092. [CrossRef]

119. Lagier-Tourenne, C.; Polymenidou, M.; Hutt, K.R.; Vu, A.Q.; Baughn, M.; Huelga, S.C.; Clutario, K.M.; Ling, S.C.; Liang, T.Y.; Mazur, C.; et al. Divergent roles of ALS-linked proteins FUS/TLS and TDP-43 intersect in processing long pre-mRNAs. Nat. Neurosci. 2012, 15, 1488-1497. [CrossRef]

120. Joyce, P.I.; Fratta, P.; Fisher, E.M.; Acevedo-Arozena, A. SOD1 and TDP-43 animal models of amyotrophic lateral sclerosis: Recent advances in understanding disease toward the development of clinical treatments. Mamm. Genome 2011, 22, 420-448. [CrossRef]

121. Tsao, W.; Jeong, Y.H.; Lin, S.; Ling, J.; Price, D.L.; Chiang, P.M.; Wong, P.C. Rodent models of TDP-43: Recent advances. Brain Res. 2012, 1462, 26-39. [CrossRef]

122. Xu, Z.S. Does a loss of TDP-43 function cause neurodegeneration? Mol. Neurodegener. 2012, 7, 27. [CrossRef] [PubMed]

123. Ebstein, S.Y.; Yagudayeva, I.; Shneider, N.A. Mutant TDP-43 Causes Early-Stage Dose-Dependent Motor Neuron Degeneration in a TARDBP Knockin Mouse Model of ALS. Cell Rep. 2019, 26, 364-373.e364. [CrossRef] [PubMed]

124. Watanabe, S.; Oiwa, K.; Murata, Y.; Komine, O.; Sobue, A.; Endo, F.; Takahashi, E.; Yamanaka, K. ALS-linked TDP-43M337V knock-in mice exhibit splicing deregulation without neurodegeneration. Mol. Brain 2020, 13, 8. [CrossRef] [PubMed]

125. Vance, C.; Rogelj, B.; Hortobagyi, T.; De Vos, K.J.; Nishimura, A.L.; Sreedharan, J.; Hu, X.; Smith, B.; Ruddy, D.; Wright, P.; et al. Mutations in FUS, an RNA processing protein, cause familial amyotrophic lateral sclerosis type 6. Science 2009, 323, 1208-1211. [CrossRef]

126. Millecamps, S.; Salachas, F.; Cazeneuve, C.; Gordon, P.; Bricka, B.; Camuzat, A.; Guillot-Noel, L.; Russaouen, O.; Bruneteau, G.; Pradat, P.F.; et al. SOD1, ANG, VAPB, TARDBP, and FUS mutations in familial amyotrophic lateral sclerosis: Genotype-phenotype correlations. J. Med. Genet. 2010, 47, 554-560. [CrossRef]

127. Waibel, S.; Neumann, M.; Rosenbohm, A.; Birve, A.; Volk, A.E.; Weishaupt, J.H.; Meyer, T.; Muller, U.; Andersen, P.M.; Ludolph, A.C. Truncating mutations in FUS/TLS give rise to a more aggressive ALS-phenotype than missense mutations: A clinico-genetic study in Germany. Eur. J. Neurol. 2013, 20, 540-546. [CrossRef]

128. Chio, A.; Calvo, A.; Mazzini, L.; Cantello, R.; Mora, G.; Moglia, C.; Corrado, L.; D'Alfonso, S.; Majounie, E.; Renton, A.; et al. Extensive genetics of ALS: A population-based study in Italy. Neurology 2012, 79, 1983-1989. [CrossRef] 
129. Hubers, A.; Just, W.; Rosenbohm, A.; Muller, K.; Marroquin, N.; Goebel, I.; Hogel, J.; Thiele, H.; Altmuller, J.; Nurnberg, P.; et al. De novo FUS mutations are the most frequent genetic cause in early-onset German ALS patients. Neurobiol. Aging 2015, 36, 3117.e3111-3117.e3116. [CrossRef]

130. Zinszner, H.; Sok, J.; Immanuel, D.; Yin, Y.; Ron, D. TLS (FUS) binds RNA in vivo and engages in nucleo-cytoplasmic shuttling. J. Cell Sci. 1997, 110, 1741-1750.

131. Kim, H.J.; Taylor, J.P. Lost in Transportation: Nucleocytoplasmic Transport Defects in ALS and Other Neurodegenerative Diseases. Neuron 2017, 96, 285-297. [CrossRef]

132. Belly, A.; Moreau-Gachelin, F.; Sadoul, R.; Goldberg, Y. Delocalization of the multifunctional RNA splicing factor TLS/FUS in hippocampal neurones: Exclusion from the nucleus and accumulation in dendritic granules and spine heads. Neurosci. Lett. 2005, 379, 152-157. [CrossRef] [PubMed]

133. Yasuda, K.; Zhang, H.; Loiselle, D.; Haystead, T.; Macara, I.G.; Mili, S. The RNA-binding protein Fus directs translation of localized mRNAs in APC-RNP granules. J. Cell. Biol. 2013, 203, 737-746. [CrossRef] [PubMed]

134. Liu-Yesucevitz, L.; Bassell, G.J.; Gitler, A.D.; Hart, A.C.; Klann, E.; Richter, J.D.; Warren, S.T.; Wolozin, B. Local RNA translation at the synapse and in disease. J. Neurosci. 2011, 31, 16086-16093. [CrossRef] [PubMed]

135. Sephton, C.F.; Tang, A.A.; Kulkarni, A.; West, J.; Brooks, M.; Stubblefield, J.J.; Liu, Y.; Zhang, M.Q.; Green, C.B.; Huber, K.M.; et al. Activity-dependent FUS dysregulation disrupts synaptic homeostasis. Proc. Natl. Acad. Sci. USA 2014, 111, E4769-E4778. [CrossRef]

136. Kamelgarn, M.; Chen, J.; Kuang, L.; Jin, H.; Kasarskis, E.J.; Zhu, H. ALS mutations of FUS suppress protein translation and disrupt the regulation of nonsense-mediated decay. Proc. Natl. Acad. Sci. USA 2018, 115, E11904. [CrossRef]

137. Nakaya, T.; Maragkakis, M. Amyotrophic Lateral Sclerosis associated FUS mutation shortens mitochondria and induces neurotoxicity. Sci. Rep. 2018, 8, 15575. [CrossRef]

138. Kino, Y.; Washizu, C.; Kurosawa, M.; Yamada, M.; Miyazaki, H.; Akagi, T.; Hashikawa, T.; Doi, H.; Takumi, T.; Hicks, G.G.; et al. FUS/TLS deficiency causes behavioral and pathological abnormalities distinct from amyotrophic lateral sclerosis. Acta Neuropathol. Commun. 2015, 3, 24. [CrossRef]

139. Sharma, A.; Lyashchenko, A.K.; Lu, L.; Nasrabady, S.E.; Elmaleh, M.; Mendelsohn, M.; Nemes, A.; Tapia, J.C.; Mentis, G.Z.; Shneider, N.A. ALS-associated mutant FUS induces selective motor neuron degeneration through toxic gain of function. Nat. Commun. 2016, 7, 10465. [CrossRef]

140. Sasayama, H.; Shimamura, M.; Tokuda, T.; Azuma, Y.; Yoshida, T.; Mizuno, T.; Nakagawa, M.; Fujikake, N.; Nagai, Y.; Yamaguchi, M. Knockdown of the Drosophila fused in sarcoma (FUS) homologue causes deficient locomotive behavior and shortening of motoneuron terminal branches. PLoS ONE 2012, 7, e39483. [CrossRef]

141. Huang, C.; Zhou, H.; Tong, J.; Chen, H.; Liu, Y.J.; Wang, D.; Wei, X.; Xia, X.G. FUS transgenic rats develop the phenotypes of amyotrophic lateral sclerosis and frontotemporal lobar degeneration. PLoS Genet. 2011, 7, e1002011. [CrossRef]

142. Chen, Y.; Yang, M.; Deng, J.; Chen, X.; Ye, Y.; Zhu, L.; Liu, J.; Ye, H.; Shen, Y.; Li, Y.; et al. Expression of human FUS protein in Drosophila leads to progressive neurodegeneration. Protein Cell 2011, 2, 477-486. [CrossRef] [PubMed]

143. An, H.; Skelt, L.; Notaro, A.; Highley, J.R.; Fox, A.H.; La Bella, V.; Buchman, V.L.; Shelkovnikova, T.A. ALS-linked FUS mutations confer loss and gain of function in the nucleus by promoting excessive formation of dysfunctional paraspeckles. Acta Neuropathol. Commun. 2019, 7, 7. [CrossRef] [PubMed]

144. Renton, A.E.; Majounie, E.; Waite, A.; Simon-Sanchez, J.; Rollinson, S.; Gibbs, J.R.; Schymick, J.C.; Laaksovirta, H.; van Swieten, J.C.; Myllykangas, L.; et al. A hexanucleotide repeat expansion in C9ORF72 is the cause of chromosome 9p21-linked ALS-FTD. Neuron 2011, 72, 257-268. [CrossRef] [PubMed]

145. Iacoangeli, A.; Al Khleifat, A.; Jones, A.R.; Sproviero, W.; Shatunov, A.; Opie-Martin, S.; Morrison, K.E.; Shaw, P.J.; Shaw, C.E.; Fogh, I.; et al. C9orf72 intermediate expansions of 24-30 repeats are associated with ALS. Acta Neuropathol. Commun. 2019, 7, 115. [CrossRef] [PubMed]

146. Balendra, R.; Isaacs, A.M. C9orf72-mediated ALS and FTD: Multiple pathways to disease. Nat. Rev. Neurol. 2018, 14, 544-558. [CrossRef] [PubMed]

147. Haeusler, A.R.; Donnelly, C.J.; Rothstein, J.D. The expanding biology of the C9orf72 nucleotide repeat expansion in neurodegenerative disease. Nat. Rev. Neurosci. 2016, 17, 383-395. [CrossRef]

148. Aoki, Y.; Manzano, R.; Lee, Y.; Dafinca, R.; Aoki, M.; Douglas, A.G.L.; Varela, M.A.; Sathyaprakash, C.; Scaber, J.; Barbagallo, P.; et al. C9orf72 and RAB7L1 regulate vesicle trafficking in amyotrophic lateral sclerosis and frontotemporal dementia. Brain 2017, 140, 887-897. [CrossRef] 
149. Nassif, M.; Woehlbier, U.; Manque, P.A. The Enigmatic Role of C9ORF72 in Autophagy. Front. Neurosci 2017, 11, 442. [CrossRef]

150. Mizielinska, S.; Isaacs, A.M. C9orf72 amyotrophic lateral sclerosis and frontotemporal dementia: Gain or loss of function? Curr. Opin. Neurol. 2014, 27, 515-523. [CrossRef]

151. Zhang, K.; Donnelly, C.J.; Haeusler, A.R.; Grima, J.C.; Machamer, J.B.; Steinwald, P.; Daley, E.L.; Miller, S.J.; Cunningham, K.M.; Vidensky, S.; et al. The C9orf72 repeat expansion disrupts nucleocytoplasmic transport. Nature 2015, 525, 56-61. [CrossRef]

152. Farg, M.A.; Sundaramoorthy, V.; Sultana, J.M.; Yang, S.; Atkinson, R.A.; Levina, V.; Halloran, M.A.; Gleeson, P.A.; Blair, I.P.; Soo, K.Y.; et al. C9ORF72, implicated in amytrophic lateral sclerosis and frontotemporal dementia, regulates endosomal trafficking. Hum. Mol. Genet. 2014, 23, 3579-3595. [CrossRef] [PubMed]

153. Burk, K.; Pasterkamp, R.J. Disrupted neuronal trafficking in amyotrophic lateral sclerosis. Acta Neuropathol. 2019, 137, 859-877. [CrossRef] [PubMed]

154. Hubers, A.; Marroquin, N.; Schmoll, B.; Vielhaber, S.; Just, M.; Mayer, B.; Hogel, J.; Dorst, J.; Mertens, T.; Just, W.; et al. Polymerase chain reaction and Southern blot-based analysis of the C9orf72 hexanucleotide repeat in different motor neuron diseases. Neurobiol. Aging 2014, 35, 1214.e1-1214.e6. [CrossRef] [PubMed]

155. Boeve, B.F.; Boylan, K.B.; Graff-Radford, N.R.; DeJesus-Hernandez, M.; Knopman, D.S.; Pedraza, O.; Vemuri, P.; Jones, D.; Lowe, V.; Murray, M.E.; et al. Characterization of frontotemporal dementia and/or amyotrophic lateral sclerosis associated with the GGGGCC repeat expansion in C9ORF72. Brain 2012, 135, 765-783. [CrossRef] [PubMed]

156. Devenney, E.; Hornberger, M.; Irish, M.; Mioshi, E.; Burrell, J.; Tan, R.; Kiernan, M.C.; Hodges, J.R. Frontotemporal dementia associated with the C9ORF72 mutation: A unique clinical profile. JAMA Neurol. 2014, 71, 331-339. [CrossRef] [PubMed]

157. Waite, A.J.; Baumer, D.; East, S.; Neal, J.; Morris, H.R.; Ansorge, O.; Blake, D.J. Reduced C9orf72 protein levels in frontal cortex of amyotrophic lateral sclerosis and frontotemporal degeneration brain with the C9ORF72 hexanucleotide repeat expansion. Neurobiol. Aging 2014, 35, 1779.e5-1779.e13. [CrossRef]

158. Xiao, S.; MacNair, L.; McGoldrick, P.; McKeever, P.M.; McLean, J.R.; Zhang, M.; Keith, J.; Zinman, L.; Rogaeva, E.; Robertson, J. Isoform-specific antibodies reveal distinct subcellular localizations of C9orf72 in amyotrophic lateral sclerosis. Ann. Neurol. 2015, 78, 568-583. [CrossRef]

159. Koppers, M.; Blokhuis, A.M.; Westeneng, H.J.; Terpstra, M.L.; Zundel, C.A.; Vieira de Sa, R.; Schellevis, R.D.; Waite, A.J.; Blake, D.J.; Veldink, J.H.; et al. C9orf72 ablation in mice does not cause motor neuron degeneration or motor deficits. Ann. Neurol. 2015, 78, 426-438. [CrossRef]

160. Foxe, D.; Elan, E.; Burrell, J.R.; Leslie, F.V.C.; Devenney, E.; Kwok, J.B.; Halliday, G.M.; Hodges, J.R.; Piguet, O. Intrafamilial Phenotypic Variability in the C9orf72 Gene Expansion: 2 Case Studies. Front. Psychol. 2018, 9, 1615. [CrossRef]

161. Couthouis, J.; Hart, M.P.; Shorter, J.; DeJesus-Hernandez, M.; Erion, R.; Oristano, R.; Liu, A.X.; Ramos, D.; Jethava, N.; Hosangadi, D.; et al. A yeast functional screen predicts new candidate ALS disease genes. Proc. Natl. Acad. Sci. USA 2011, 108, 20881. [CrossRef]

162. Yoon, Y.; Park, H.; Kim, S.; Nguyen, P.T.; Hyeon, S.J.; Chung, S.; Im, H.; Lee, J.; Lee, S.B.; Ryu, H. Genetic Ablation of EWS RNA Binding Protein 1 (EWSR1) Leads to Neuroanatomical Changes and Motor Dysfunction in Mice. Exp. Neurobiol. 2018, 27, 103-111. [CrossRef] [PubMed]

163. Lattante, S.; Pomponi, M.G.; Conte, A.; Marangi, G.; Bisogni, G.; Patanella, A.K.; Meleo, E.; Lunetta, C.; Riva, N.; Mosca, L.; et al. ATXN1 intermediate-length polyglutamine expansions are associated with amyotrophic lateral sclerosis. Neurobiol. Aging 2018, 64, 157.e151-157.e155. [CrossRef] [PubMed]

164. Aditi; Glass, L.; Dawson, T.R.; Wente, S.R. An amyotrophic lateral sclerosis-linked mutation in GLE1 alters the cellular pool of human Gle1 functional isoforms. Adv. Biol. Regul. 2016, 62, 25-36. [CrossRef] [PubMed]

165. Forman, M.S.; Mackenzie, I.R.; Cairns, N.J.; Swanson, E.; Boyer, P.J.; Drachman, D.A.; Jhaveri, B.S.; Karlawish, J.H.; Pestronk, A.; Smith, T.W.; et al. Novel Ubiquitin Neuropathology in Frontotemporal Dementia With Valosin-Containing Protein Gene Mutations. J. Neuropathol. Exp. Neurol. 2006, 65, 571-581. [CrossRef]

166. Borghero, G.; Pugliatti, M.; Marrosu, F.; Marrosu, M.G.; Murru, M.R.; Floris, G.; Cannas, A.; Occhineri, P.; Cau, T.B.; Loi, D.; et al. TBK1 is associated with ALS and ALS-FTD in Sardinian patients. Neurobiol. Aging 2016, 43, 180. [CrossRef] 
167. Münch, C.; Sedlmeier, R.; Meyer, T.; Homberg, V.; Sperfeld, A.D.; Kurt, A.; Prudlo, J.; Peraus, G.; Hanemann, C.O.; Stumm, G.; et al. Point mutations of the p150 subunit of dynactin (DCTN1) gene in ALS. Neurology 2004, 63, 724. [CrossRef]

168. Figlewicz, D.A.; Krizus, A.; Martinoli, M.G.; Meininger, V.; Dib, M.; Rouleau, G.A.; Julien, J.-P. Variants of the heavy neurofilament subunit are associated with the development of amyotrophic lateral sclerosis. Hum. Mol. Genet. 1994, 3, 1757-1761. [CrossRef]

169. Brenner, D.; Müller, K.; Wieland, T.; Weydt, P.; Böhm, S.; Lulé, D.; Hübers, A.; Neuwirth, C.; Weber, M.; Borck, G.; et al. NEK1 mutations in familial amyotrophic lateral sclerosis. Brain 2016, 139, e28. [CrossRef]

170. Van Rheenen, W.; Shatunov, A.; Dekker, A.M.; McLaughlin, R.L.; Diekstra, F.P.; Pulit, S.L.; van der Spek, R.A.A.; Võsa, U.; de Jong, S.; Robinson, M.R.; et al. Genome-wide association analyses identify new risk variants and the genetic architecture of amyotrophic lateral sclerosis. Nat. Genet. 2016, 48, 1043-1048. [CrossRef]

171. Bannwarth, S.; Ait-El-Mkadem, S.; Chaussenot, A.; Genin, E.C.; Lacas-Gervais, S.; Fragaki, K.; Berg-Alonso, L.; Kageyama, Y.; Serre, V.; Moore, D.G.; et al. A mitochondrial origin for frontotemporal dementia and amyotrophic lateral sclerosis through CHCHD10 involvement. Brain 2014, 137, 2329-2345. [CrossRef]

172. Deschauer, M.; Gaul, C.; Behrmann, C.; Prokisch, H.; Zierz, S.; Haack, T.B. C19orf12 mutations in neurodegeneration with brain iron accumulation mimicking juvenile amyotrophic lateral sclerosis. J. Neurol. 2012, 259, 2434-2439. [CrossRef] [PubMed]

173. Geevasinga, N.; Menon, P.; Ng, K.; Van Den Bos, M.; Byth, K.; Kiernan, M.C.; Vucic, S. Riluzole exerts transient modulating effects on cortical and axonal hyperexcitability in ALS. Amyotroph Lateral Scler Front. Degener 2016, 17, 580-588. [CrossRef] [PubMed]

174. Blasco, H.; Mavel, S.; Corcia, P.; Gordon, P.H. The glutamate hypothesis in ALS: Pathophysiology and drug development. Curr. Med. Chem. 2014, 21, 3551-3575. [CrossRef] [PubMed]

175. Ryu, H.; Smith, K.; Camelo, S.I.; Carreras, I.; Lee, J.; Iglesias, A.H.; Dangond, F.; Cormier, K.A.; Cudkowicz, M.E.; Brown, R.H., Jr.; et al. Sodium phenylbutyrate prolongs survival and regulates expression of anti-apoptotic genes in transgenic amyotrophic lateral sclerosis mice. J. Neurochem. 2005, 93, 1087-1098. [CrossRef] [PubMed]

176. Lee, J.; Ryu, H.; Keum, G.; Yoon, Y.J.; Kowall, N.W.; Ryu, H. Therapeutic Targeting of Epigenetic Components in Amyotrophic Lateral Sclerosis (ALS). Curr. Med. Chem. 2014, 21, 3576-3582. [CrossRef]

177. Lee, J.; Ryu, H. Epigenetic modification is linked to Alzheimer's disease: Is it a maker or a marker? BMB Rep. 2010, 43, 649-655. [CrossRef]

178. Lee, J.; Hwang, Y.J.; Kim, K.Y.; Kowall, N.W.; Ryu, H. Epigenetic mechanisms of neurodegeneration in Huntington's disease. Neurotherapeutics 2013, 10, 664-676. [CrossRef]

Publisher's Note: MDPI stays neutral with regard to jurisdictional claims in published maps and institutional affiliations.

(C) 2020 by the authors. Licensee MDPI, Basel, Switzerland. This article is an open access article distributed under the terms and conditions of the Creative Commons Attribution (CC BY) license (http://creativecommons.org/licenses/by/4.0/). 